\title{
Two new species of Odontostilbe historically hidden under O. microcephala (Characiformes: Cheirodontinae)
}

\author{
Junior Chuctaya ${ }^{1,2}$, Cristina M. Bührnheim ${ }^{3,4}$ and Luiz R. Malabarba ${ }^{1}$
}

Specimens historically identified as Odontostilbe microcephala from the upper rio Paraná and Andean piedmont tributaries of the río Paraguay are reviewed and split in three species. We found that the distribution of O. microcephala is restricted to the Andean slope of the río Paraguay basin. The species is distinguished from congeners with subterminal mouth by the elongate body, usually 10-12 gill rakers on upper branch and smaller horizontal orbital diameter (24.6-32.8 \% HL, mean 28.7\%). Specimens from upper rio Paraná constitute two new species, diagnosed from other Cheirodontinae by the presence of mesopterygoid teeth, grouped on median portion and forming a continuous row. The new species are distinguished from each other by having premaxillary teeth with five cusps $v s$. nine cusps and by the number of lamellae in left and right sides of central median raphe of olfactory rosette with 20-21 vs. 11-12.

Keywords: Biodiversity, Characidae, La Plata River basin, Mesopterygoid teeth, Taxonomy.

Espécimes historicamente identificados com Odontostilbe microcephala do rio Paraná e tributários do río Paraguay, foram revisados e separados em três espécies. A distribuição de O. microcephala é restrita ao sopé andino da bacia do río Paraguay. A espécie é distinta das congêneres com boca subterminal pela forma alongada, geralmente 10-12 rastros branquiais no ramo superior e menor diâmetro horizontal da órbita (24,6-32,8 \% CC, média 28,7\%). Espécimes do alto rio Paraná constituem duas espécies novas diagnosticadas de outros Cheirodontinae pela presença de dentes no mesopterigoide, agrupados em sua porção média e formando uma fileira continua. As novas espécies distinguem-se por ter dentes premaxilares com cinco cúspides vs. nove cúspides e pelo número de lamelas nos lados esquerdo e direito da rafe central da roseta olfativa com 20-21 vs. 11-12.

Palavras-chave: Bacia do rio da Prata, Biodiversidade, Characidae, Dentes do Mesopterigoide, Taxonomia.

\section{Introduction}

Species of Cheirodontinae are found in most river drainages of Central and South America, occurring from Costa Rica to central Chile and Argentina, in both Atlantic and Pacific drainages of the Andes (Malabarba, 2003). The subfamily includes 18 genera and 66 valid species, of which almost half (8) of the genera and almost one third (19) of the species were described in the last twenty years (Malabarba, 1998, 2003; Malabarba, Bertaco, 1999; Malabarba, Weitzman, 1999, 2000; Weitzman, Malabarba, 1999; Malabarba et al., 2004; Bührnheim, Malabarba, 2006, 2007; Bührnheim et al., 2008; Malabarba, Jerep, 2012, 2014; Jerep, Malabarba, 2014; Zarske, 2012; Vari et al., 2016; Jerep et al., 2016).
Currently there are 14 valid species of Odontostilbe (Bührnheim, Malabarba, 2006, 2007): O. dierythrura Fowler; $O$. ecuadorensis Bührnheim \& Malabarba; O. euspilurus (Fowler); O. fugitiva Cope; O. microcephala Eigenmann; O. nareuda Bührnheim \& Malabarba; O. pao Eigenmann $\&$ Kennedy; $O$. paraguayensis Eigenmann \& Kennedy; $O$. parecis Bührnheim \& Malabarba; O. pequira (Steindachner); O. pulchra (Gill); and O. splendida Bührnheim \& Malabarba. Malabarba (1998) considered that "Odontostilbe" dialeptura (Fink, Weitzman, 1974) and "Odontostilbe" mitoptera (Fink, Weitzman, 1974) from Pacific rivers in Costa Rica and Panama are possibly not part of the genus Odontostilbe. Those two species are currently hypothesized to be related to compsurin cheirodontines, but remain referred to Odontostilbe in the lack of a proper generic name (Bührnheim, Malabarba, 2006).

${ }^{1}$ Programa de Pós-Graduação em Biologia Animal, Departamento de Zoologia, Universidade Federal do Rio Grande do Sul, Av. Bento Gonçalves 9500, 91501-970 Porto Alegre, RS, Brazil. (JC) junior.chuctaya@gmail.com, Dhttps://orcid.org/0000-0002-8876-4675 (corresponding author), (LRM) malabarb@ufrgs.br

${ }^{2}$ Laboratorio de Ictiología, Museo de Historía Natural, Universidad Nacional Mayor de San Marcos, Av. Arenales 1256, Lima 14, Peru. ${ }^{3}$ Universidade do Estado do Amazonas, ENS, Av. Djalma Batista, Chapada 2470, 69050-010 Manaus, AM, Brazil. cmbuhrn@yahoo.com.br ${ }^{4}$ Instituto de Ciências Biológicas, Departamento de Biologia, Coleção Zoólogica Prof. Paulo Bührnheim, Universidade Federal do Amazonas, Minicampus (Setor Sul). Av. Rodrigo Octávio Jordão Ramos, 6200, Coroado I, 69080-900, Manaus, AM, Brazil. 
Odontostilbe microcephala was described by Eigenmann in Eigenmann, Ogle (1907) based on two specimens from río Pilcomayo, Bolivia, a tributary of the río Paraguay. Later, the species was redescribed by Eigenmann (1915) in his monograph on Cheirodontinae, with the examination of additional material from the rio Tietê, expanding the distribution of the species to the upper rio Paraná. After Eigenmann, several studies referred O. microcephala from both río Paraguay and/or upper rio Paraná drainages (e.g., $\mathrm{Uj}$, 1987; Miquelarena et al., 2008; Oyakawa, Menezes, 2011).

The examination of the specimens from Eigenmann (1907, 1915) along with additional new material proved the specimens from upper rio Paraná to belong to two new species, restricting the occurrence of Odontostilbe microcephala to tributaries of río Paraguay. Herein we provide a redescription of Odontostilbe microcephala and the description of those two new species of Odontostilbe following the definition of Malabarba (1998).

\section{Material and Methods}

Counts and measurements follow Fink, Weitzman (1974). Measurements corresponding to parts of the head were taken in stereomicroscope. Measurements from lateral side of body were taken from projections on the main axis of the body, with digital caliper and expressed to the nearest $0.1 \mathrm{~mm}$. Head length is the distance between the tip of the snout and the posterior end of subopercle, which is slightly posterior to the margin of the opercle (Bührnheim, Malabarba, 2006). Measurements are presented in tables as percent of the standard length (SL), except for subunits of the head, which are presented as percent of the head length (HL).

Precaudal, caudal, and total vertebral counts include the four vertebrae of the Weberian apparatus, and the terminal "half centrum" as a single element (Malabarba, Weitzman 1999). The gill raker at the junction of ceratobranchial and epibranchial is counted jointly with the gill rakers on the lower branch as in Bührnheim, Malabarba (2006). The last two analfin rays are counted as a single element for being supported by the same pterygiophore. For the description of secondary sexual characters (presence of bony-hooks in fins), the fin is divided into three regions, proximal (from the base of the ray to its first bifurcation), median (between the first and second bifurcation of ray) and distal (from second bifurcation to the distal tip of the ray).

Specimens were cleared and stained (c\&s) according to Taylor, Van Dyke (1985) and used for counting vertebrae, teeth, gill rakers, denticulation in gill rakers, supraneurals and proximal pterygiophores. Radiographs of type specimens of Odontostilbe microcephala were made by The California Academy of Sciences-Ichthyology Section, and were used for counting vertebrae and fin rays. Scanning Electron Microscope (SEM) images were obtained from dentition and denticulation of gill rakers. Pictures of supraneurals were taken from cleared and stained specimens with a camera attached to a stereomicroscope. Nomenclature of bones follows Weitzman (1962).

The following institutions provided material for the study: ANSP, The Academy of Natural Sciences, Philadelphia, USA; CAS, California Academy of Sciences, San Francisco, USA; FMNH, Field Museum of Natural History, Chicago, USA; MHNG, Muséum d'histoire naturelle, Genève, Switzerland; INPA, Instituto Nacional de Pesquisas da Amazônia, Manaus, Brazil; INHS, Illinois Natural History Survey, Illinois, USA; MCP, Museu de Ciências e Tecnologia da PUCRS, Porto Alegre, Brazil; MZUSP, Museu de Zoologia da Universidade de São Paulo, São Paulo, Brazil; USNM, National Museum of Natural History, Washington D.C., USA. UMSS, Universidad Mayor de San Simon, Cochabamba, Bolivia; UFRGS, Universidade Federal do Rio Grande do Sul, Departamento de Zoologia, Porto Alegre, Brazil.

Statistical analyses. The standard length was not used as a variable and the remaining morphometric variables were standardized as the ratio against the standard length and coded as follows: M1 (snout to anal-fin origin), M2 (snout to dorsalfin origin), M3 (snout to pelvic-fin origin), M4 (snout to pectoral-fin origin), M5 (dorsal-fin origin to caudal-fin origin), M6 (orbit to dorsal-fin origin), M7 (anal-fin base length), M8 (length of caudal peduncle), M9 (depth of caudal peduncle), M10 (body depth at dorsal fin), M11 (dorsal-fin length), M12 (pelvic-fin length), M13 (pectoral-fin length), M14 (head length), M15 (snout length), M16 (upper jaw length), M17 (horizontal orbit diameter) and M18 (interorbital width).

The combined measurement data were examined with Principal Components Analysis (PCA) calculated in Past 3.x version 2016 (Hammer et al., 2001) to determine if distinct groups were identified. Defined groups were then analyzed with the algorithm of Variable selection to discriminate among taxonomic groups (VARSEDIG) (Guisande et al., 2016; Guisande-González, 2016). VARSEDIG was used to identify the morphometric characters that significantly discriminate two taxa and validate the morphological distinctness between them via a Monte-Carlo method. For analysis with the VARSEDIG algorithm 18 morphometric variables were selected, grouped by species and sex. Since this method only allows to discrimination between two groups, species 1 vs. 2 , 2 vs. 3 and 1 vs. 3 were compared. Moreover, female and male individuals for each species were compared. Overlap methods were used to prioritize the variables according to their capacity for discrimination. It was obtained a density curve for each variable and the overlap of the area under the curve between the two groups was estimated for all variables. Variables with lower overlap should have better discrimination capacities and, hence, all variables were ordered from lowest to highest overlap. To eliminate variables that are not significant, a regression by steps was applied. VARSEDIG by default established other parameters. These are the estimated mean $\mathrm{X}$ and $\mathrm{Y}$ polar coordinates for both groups and the Euclidean distance of these means that is calculated between both groups. Algorithm for variable selection followed Guisande et al. (2016) and Guisande-González (2016). Figures of density, 
polar coordinates and bivariate randomization test show plots obtained with VARSEDIG and the variables that had better discrimination between two compared species were selected. A density plot was depicted for the quantitative variable with lower overlap between both groups and, thus, the highest discrimination capacity. For two compared species, the scatterplot of polar coordinates using variables selected with highest discrimination capacity was performed. Two figures were obtained with the results of a bivariate randomization test, one with the value of the individual of species 1 (red point), with the higher probability (p-value) of belonging to species 2 and the second with value of the individual of species 2 (red point) with the highest p-value of belonging to species 1 , respectively. If when comparing group 1 with group 2 and group 2 with 1, the p-value is close to, or lower than, 0.05 for the $\mathrm{X}$ or $\mathrm{Y}$ polar coordinates, it is concluded that the selected variables are significantly contributing to discriminate between both species.

Quantitative variables were represented by graphical a boxplot. A version of this type of graphic is to add an element, called "notch" representing approximate confidence intervals $95 \%$ for median: two medians are different (the groups are different) if intervals or notches corresponding boxes do not overlap.

All statistical analyses were performed using $\mathrm{R}$ ( $\mathrm{R}$ Development Core Team, 2016), with the exception of Principal Components Analysis (PCA) which were calculated in Past 3.x version 2016 (Hammer et al., 2001). The boxplot graph was performed using "sm" package (Bowman, Azzalini, 2013). VARSEDIG was implemented with the aid of the following R packages: adehabitatHR, adehabitatHS, adehabitatLT and adehabitatMA packages (Calenge, 2006); ade4 package (Chessel et al., 2004; Dray et al., 2007; Dray et al., 2015); sp package (Pebesma, Bivand, 2005; Bivand et al., 2013); deldir package (Turner, 2016); CircStats package (Lund, Agostinelli, 2012); MASS package (Venables, Ripley, 2002); boot package (Davison, Hinkley, 1997; Canty, Ripley, 2016); kulife package (Ekstrom et al., 2013) and car package (Fox, Weisberg, 2011). Geographic distribution map was performed in the Quantum GIS version 2.8 software (Quantum GIS Development Team, 2016).

\section{Results}

\section{Odontostilbe weitzmani, new species}

urn:1sid:zoobank.org:act:B3D5A4C7-DF4C-482A-83B90147BE3C60FE

\section{Figs. 1-5}

Odontostilbe microcephala non Eigenmann, 1907. -Eigenmann, 1915 [in part]: 94-95 [three smaller specimens from CM 6854ac (FMNH 131317, 35.9-38.8 mm SL) and ten specimens from CM 6855 (CAS 60508, 3, 25.0-39.4 mm SL) and FMNH 57872
(7, 21.4-23.9 mm SL)] from rio Tietê at Salto Avanhandava above the falls, São Paulo, upper rio Paraná basin]. -Uj, 1987: 132 (key), 138 (description), 154 (osteological description of skull, dorsal and anal fins, generic position), 160 (distribution).

Odontostilbe sp. - Santos et al., 2017: e20160196, 4, fig. 3(t) [checklist].

Holotype. MZUSP 121648, $42.5 \mathrm{~mm}$ SL, Itirapina, São Paulo State. Lapa stream near the mouth and along the seawall of rock and the bridge on the road, $22^{\circ} 22^{\prime} 35.5^{\prime \prime} \mathrm{S}$ $47^{\circ} 46^{\prime} 55.6^{\prime \prime} \mathrm{W}, 31$ Jan 2002, E. N. Fragoso.

Paratypes. All from Brazil, upper rio Paraná basin. São Paulo State: CAS 60508, 3, 25.0-39.4 mm SL, rio Tietê at Salto Avanhandava below the falls, São Paulo, $21^{\circ} 10^{\prime} 3.5^{\prime \prime}$ S 50 $0^{\circ} 3.22^{\prime \prime} \mathrm{W}, 14$ Sep 1908, J. D. Haseman. FMNH 131317, 3, 35.9-38.8 mm SL, rio Tietê at Salto Avanhandava below the falls $21^{\circ} 10^{\prime} 03^{\prime \prime} \mathrm{S} 50^{\circ} 7^{\prime} 03^{\prime \prime} \mathrm{W}, 15$ Sep 1908, J. D. Haseman. FMNH 57872, 7, 21.4-23.9 mm SL, rio Tietê at Salto Avanhandava below the falls, São Paulo, $21^{\circ} 10^{\prime} 03^{\prime \prime} S$ $50^{\circ} 7^{\prime} 03^{\prime \prime} \mathrm{W}, 15$ Sep 1908, J. D. Haseman. MCP 32277, 2, 37.9-42.3 mm SL, rio Piracicaba, Piracicaba, tributary of rio Tietê, $22^{\circ} 43^{\prime} 19^{\prime \prime} \mathrm{S} 47^{\circ} 39^{\prime} 21^{\prime \prime} \mathrm{W}$, 29 Jan 2001, C. Lucena, J. Silva, E. Pereira \& A. Cardoso. MCP 12108, 2, 42.3-43.8 mm SL, Ilha Solteira, rio Paraná, W, 19 Oct 1969, Expedition Department of Zoology USP leg. MZUSP 42657, 186, 33.3-43.4 mm SL, rio Mogi Guaçu, Emas, Pirassununga, $21^{\circ} 55^{\prime} 00^{\prime \prime} \mathrm{S} 47^{\circ} 23^{\prime} 00^{\prime \prime} \mathrm{W}$, EEBP-Emas. MZUSP 16851, 13, 36.8-41.8 mm SL, rio Mogi Guaçu, Emas, Pirassununga, $21^{\circ} 55^{\prime} 00^{\prime \prime} \mathrm{S} 47^{\circ} 23^{\prime} 00^{\prime \prime} \mathrm{W}, 22$ Oct 1963, H. A. Britski. MZUSP 87947, 10, 42.5-50.5 mm SL, Itirapina, stream of Lapa near the mouth and along the seawall of rock and the bridge on the road, $22^{\circ} 15^{\prime} 00^{\prime \prime} \mathrm{S} 47^{\circ} 51^{\prime} 48^{\prime \prime} \mathrm{W}, 31$ Jan 2002 , E. N. Fragoso. Mato Grosso do Sul State: MCP 12105, 2, 34.2-37.2 mm SL, rio Paraná, in front of Jupiá, Três Lagoas, 11-13 Oct 1969, Expedition Department of Zoology USP leg. MZUSP 4011, 2199, 25.3-40.0 mm SL, rio Paraná, in front of Jupiá, Três Lagoas, $21^{\circ} 07^{\prime} 10^{\prime \prime} \mathrm{S} 51^{\circ} 45^{\prime} 00^{\prime \prime} \mathrm{W}, 4$ Dec 1960, P. E. Vanzolini \& S. Saiar. Goiás State: MCP 27814, 9, 39.5-50.8 mm SL, rio São Marcos, road Catalão/ Davinópolis, Catalão, $18^{\circ} 06^{\prime} 15^{\prime \prime} \mathrm{S} 47^{\circ} 41^{\prime} 35^{\prime \prime} \mathrm{W}, 23$ Jan 2001, C. Lucena, J. Silva, E. Pereira \& A. Cardoso. MCP 26001, 1, $40.3 \mathrm{~mm}$ SL, rio Corumbá, downstream UHE Corumbá, rio Paranaíba, Caldas Novas, $17^{\circ} 29^{\prime} 00^{\prime \prime} \mathrm{S} 48^{\circ} 23^{\prime} 00^{\prime \prime} \mathrm{W}, 15$ Oct 1996, Nupelia. MCP 20337, 50, 36.8-54.2, rio Corumbá, affluent of rio Paranaíba. region of the municipalities of Caldas Novas, Corumbaína, Pires do Rio and Ipameri, $18^{\circ} 00^{\prime} 00^{\prime \prime} \mathrm{S} 49^{\circ} 00^{\prime} 00^{\prime \prime} \mathrm{W}, 07$ Sep 1996, Nupelia.

Non types. All from Brazil, upper rio Paraná basin. Goiás State: MCP 25999, 2, 56.1-56.3 mm SL, rio Corumbá, near the mouth of rio Pirapitinga, (tributary of rio Paranaíba), $17^{\circ} 47^{\prime} 00^{\prime \prime} \mathrm{S} 48^{\circ} 32^{\prime} 60^{\prime \prime} \mathrm{W}, 18$ Sep 1996, Nupelia. MCP 26000, 2, 55.1-56. $8 \mathrm{~mm} \mathrm{SL}$, rio Corumbá, near the mouth of rio do Peixe (tributary of rio Paranaíba), 17 $36^{\prime} 00^{\prime \prime} \mathrm{S}$ $48^{\circ} 27^{\prime} 00^{\prime \prime} \mathrm{W}, 21$ Sep 1996, Nupelia. 
Diagnosis. Odontostilbe weitzmani differs from all species of the genus, except from Odontostilbe avanhandava, by the presence of mesopterygoid teeth, grouped on median portion of the bone, forming a continuous row (vs. absent). Odontostilbe weitzmani is distinguished from O. avanhandava by premaxillary teeth with 5(13) or 7(3) cusps [usually 5], with central cusp wider and larger than lateral cusps (vs. premaxillary teeth bearing 7-11 [usually 9] cusps, all approximately with the same size), and by the presence of 20-21 lamellae in left and right sides of central median raphe of olfactory rosette (vs. 11-12). Additionally $O$. weitzmani is distinguished from $O$. dierythrura, $O$. euspilurus, and O. microcephala by the terminal mouth (vs. subterminal mouth); from $O$. pulchra and O. ecuadorensis by the presence of hooks on first to seventh [mostly fifth to sixth] branched anal-fin rays of males ( $v s$. hooks on first to $22^{\text {nd }}$ branched anal-fin rays of males in O. pulchra, first to sixteenth in $O$. ecuadorensis); from $O$. splendida by the origin of adipose fin positioned at vertical through last anal-fin ray insertion ( $v s$. origin of adipose fin, at vertical through last 2 or 3 anal-fin rays insertion); from $O$. pao and $O$. parecis by the presence of 5-7 [mostly 5] cusps in premaxillary teeth (vs. 8-10 cusps in $O$. pao and $O$. parecis); from $O$. pequira by anterior dentary teeth with 5 cusps, being central cusp larger and longer than lateral cusps (vs. dentary with 4 anterior teeth with 3 large and equally longer compressed cusps and 2-3 lateral small cusps); and from $O$. paraguayensis by lacking fusion of supraneurals ( $v s$. fusion of supraneurals, wich are projected dorsal to musculature and skin of dorsum).

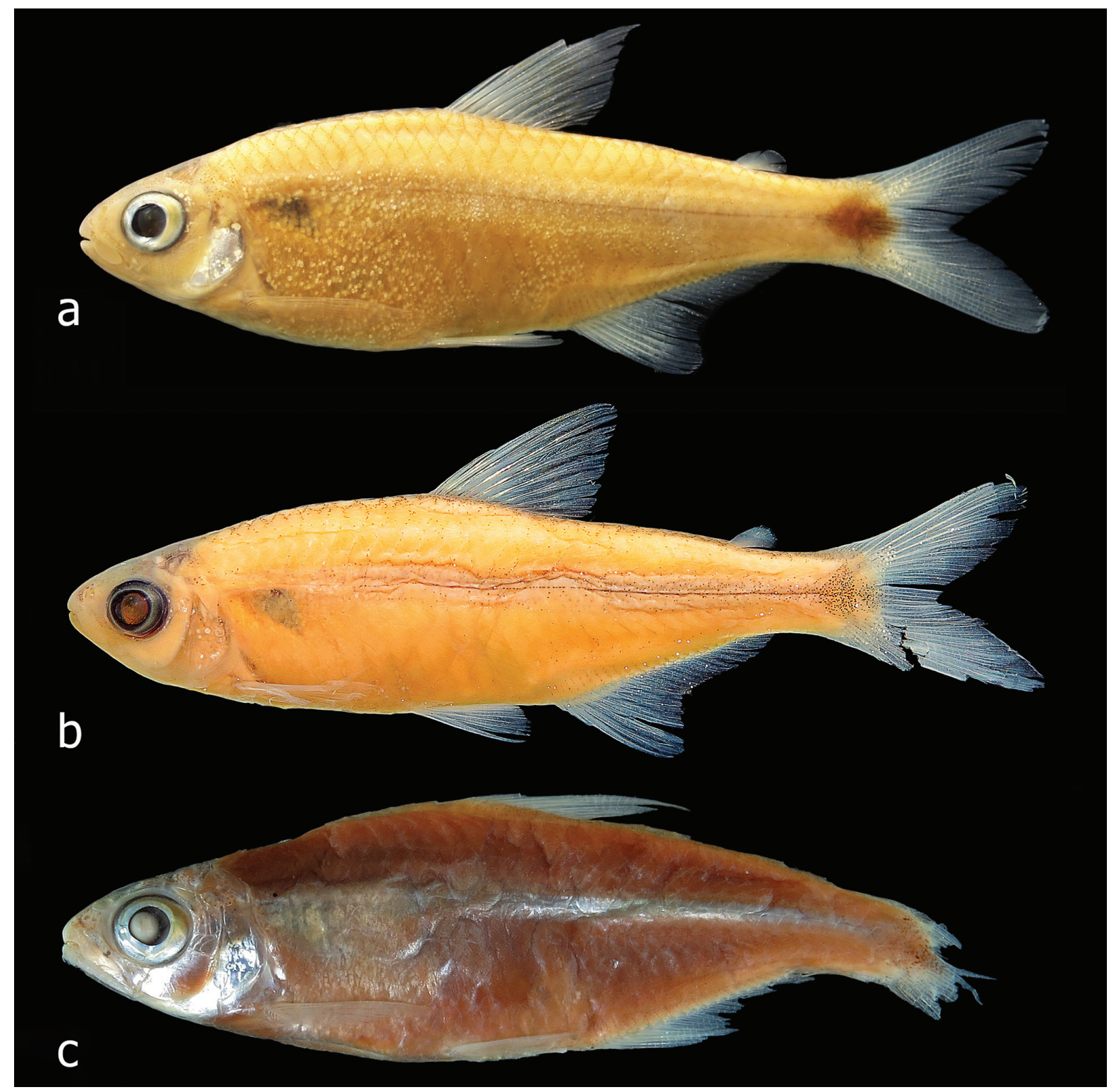

Fig. 1. Odontostilbe weitzmani: (a) holotype, MZUSP 121648, 1, 42.5 mm SL, Itirapina, São Paulo State. (b) paratype, MCP 32277, female, 42.2 mm SL, rio Piracicaba, São Paulo. (c) paratype, FMNH 131317, female, 38.7 mm SL, rio Tietê at Salto Avanhandava below the falls, São Paulo, Brazil. FMNH 131317 was listed under O. microcephala by Eigenmann (1915). 
Description. Morphometric data on Tab. 1. Body elongate and slightly compressed (Fig. 1). Greatest body depth at vertical through dorsal-fin origin. Snout slightly elongated and round. Dorsal profile of head convex from snout to vertical through anterior bony orbital margin, slightly concave from that point to distal tip of supraoccipital bone. Predorsal profile slightly convex from posterior end of supraoccipital to dorsal-fin origin. Dorsal-fin origin located anteriorly at midlength of SL. Body profile in base of dorsal fin straight to slightly convex and slightly convex from there to origin of adipose fin. Body profile between adipose-fin base and first rays of caudal fin slightly concave. Ventral profile of head slightly convex from snout to origin of pelvic fins and slightly convex from there to origin of anal fin. Body profile along base of anal fin straight or slightly convex. Ventral profile of caudal peduncle straight to slightly concave. Caudal peduncle slightly longer than deep.

Head small relative to body length, 22.8-27.7\% SL. Mouth terminal, and opening below horizontal line through middle of eye pupil. Upper and lower jaws with approximately same length. Maxilla short, posteroventrally angled, posterior tip surpassing vertical through anterior border of eye and surpassing horizontal through ventral border of eye. Teeth pedunculated distally expanded, all similar in shape. Premaxilla with 5 teeth aligned in a single row, with 5(13) or 7(3) cusps [mostly 5]. Maxilla with 2 teeth bearing 5(7) cusps. Dentary teeth with 9 gradually decreasing in size posteriorly; anterior 6, larger, bearing 5-7 cusps; followed posteriorly by smaller teeth with 1-3 cusps (Fig. 2). All jaw teeth with central cup larger and wider than lateral cusps. Ventral surface of mesopterygoid with 18-19 teeth with 1-3 cusps grouped on median portion forming a continuous row (Fig. 3).

Dorsal-fin rays ii, 9(60). First unbranched dorsal-fin ray about half-length of second unbranched dorsal-fin ray; branched rays gradually decreasing in size posteriorly. Dorsal fin with 10(5) pterygiophores. Presence of small ossification associated with first proximal dorsal-fin radial (character 124, described by Zanata, Vari, 2005). Proximal radial of first pterygiophore of dorsal fin posterior to neural spine of ninth precaudal vertebra. Medial radial fused with distal radial from first to fourth pterygiophores; as separate bony elements from fifth to tenth pterygiophores. Proximal radial of first to ninth pterygiophore with lateral projections, absent in tenth dorsal pterygiophore.

Adipose-fin origin posterior to vertical through base of last anal-fin ray. Unbranched anal-fin rays $\mathrm{v}(3)$; branched anal-fin rays $17(3), 18(20), 19(30)$, or 20(6) with 1 row of scales on base of anterior anal-fin rays. Profile of distal margin of anal fin distinctively concave forming an angle in tenth branched ray. Anal fin with 18(1), 20(3), or 21(1) pterygiophores. Medial radial fused with distal radial in first to sixth pterygiophore and no fused on remaining pterygiophores. Proximal radial of first pterygiophore in contact with hemal spine of first caudal vertebra.

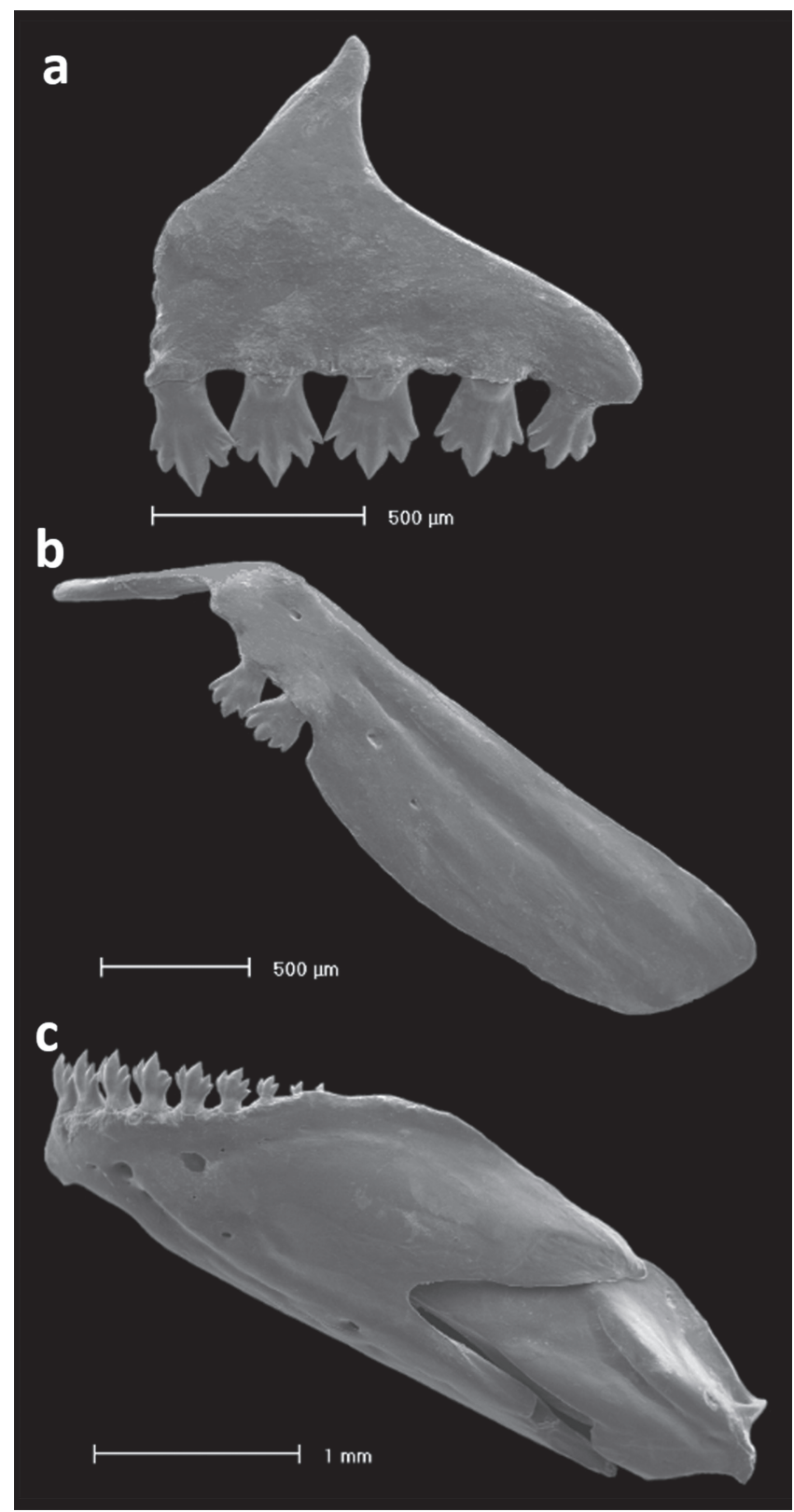

Fig. 2. Dentition of Odontostilbe weitzmani, paratype MCP 20337 male: (a) left side premaxilla, (b) maxilla, and (c) dentary, lateral view. Scanning electron micrographs (SEM).

Pectoral fin i(59), 11(22), 12(30), or 13(7). Tip of extended pectoral fin not reaching pelvic-fin origin. Pelvicfin origin anterior to vertical through dorsal-fin origin. Pelvic-fin rays i, 7(60). Principal caudal-fin rays 19(58). Dorsal procurrent caudal-fin rays $8(7), 9(2), 11(8)$, or 12(1) and ventral procurrent caudal-fin rays $7(2), 8(5), 9(15)$, or 10(4).

Cycloid scales; lateral line complete with 34(22), 35(18), $36(4)$, or 37(2) pored scales. Pre-dorsal scales in regular series with 10(2), 11(2), 12(30), 13(17) or 14(3) scales; scale rows between lateral line and dorsal line origin 5(51); scale rows between lateral line and pelvic-fin origin 3(9) or 4(42); circumpeduncular scale rows 14(14). 
Tab. 1. Morphometric data for Odontostilbe weitzmani. Number of individuals (N), mean, minimum (min), maximum (max) and standard deviation (SD) include values of the holotype (male).

\begin{tabular}{|c|c|c|c|c|c|c|c|c|c|c|c|c|c|c|c|c|}
\hline & \multirow{2}{*}{ Holotype } & \multicolumn{5}{|c|}{ Females } & \multicolumn{5}{|c|}{ Males } & \multicolumn{5}{|c|}{ Unsexed } \\
\hline & & $\mathrm{N}$ & Min & $\operatorname{Max}$ & Mean & SD & $\mathrm{N}$ & Min & $\operatorname{Max}$ & Mean & SD & $\mathrm{N}$ & Min & Max & Mean & SD \\
\hline Standard length (mm) & 42.5 & 37 & 29.9 & 50.8 & 39.3 & - & 17 & 29.8 & 43.9 & 38.0 & - & 9 & 21.4 & 25.2 & 23.5 & - \\
\hline \multicolumn{17}{|c|}{ Percents of Standard Length } \\
\hline Snout to anal-fin origin & 62.3 & 36 & 61.6 & 67.3 & 63.5 & 1.2 & 15 & 60.6 & 63.9 & 62.4 & 0.9 & 7 & 63.3 & 66.6 & 64.4 & 1.2 \\
\hline Snout to dorsal-fin origin & 46.1 & 36 & 45.3 & 51.7 & 47.9 & 1.1 & 15 & 45.4 & 49.9 & 47.2 & 1.5 & 7 & 47.9 & 52.1 & 49.9 & 1.5 \\
\hline Snout to pelvic-fin origin & 43.9 & 36 & 43.3 & 49.3 & 45.4 & 1.2 & 15 & 43.3 & 45.5 & 44.6 & 0.6 & 7 & 45.5 & 49.5 & 47.3 & 1.4 \\
\hline Snout to pectoral-fin origin & 21.9 & 36 & 20.7 & 25.8 & 23.1 & 1.1 & 15 & 21.9 & 26.6 & 23.1 & 1.2 & 7 & 24.1 & 26.4 & 25.5 & 0.8 \\
\hline Dorsal to caudal-fin origin & 51.9 & 36 & 47.7 & 54.2 & 50.9 & 1.7 & 15 & 47.3 & 53.8 & 51.6 & 1.8 & 7 & 48.1 & 51.8 & 49.9 & 1.1 \\
\hline Orbit to dorsal-fin origin & 32.1 & 36 & 31.3 & 36.1 & 33.0 & 1.2 & 15 & 30.0 & 34.7 & 32.2 & 1.4 & 7 & 29.6 & 34.9 & 32.9 & 1.8 \\
\hline Anal fin base length & 23.2 & 36 & 20.9 & 27.9 & 23.8 & 1.2 & 15 & 21.9 & 27.4 & 23.9 & 1.3 & 7 & 22.4 & 26.0 & 23.8 & 1.2 \\
\hline Length of caudal peduncle & 13.9 & 36 & 10.8 & 14.5 & 12.5 & 1.0 & 15 & 11.3 & 14.1 & 12.9 & 0.8 & 7 & 12.5 & 14.6 & 13.6 & 0.9 \\
\hline Depth of caudal peduncle & 10.5 & 36 & 9.3 & 11.1 & 10.3 & 0.4 & 15 & 9.5 & 11.0 & 10.2 & 0.5 & 7 & 9.6 & 11.7 & 10.4 & 0.7 \\
\hline Body depth at dorsal fin & 28.8 & 36 & 23.1 & 32.9 & 27.9 & 2.0 & 15 & 23.6 & 30.9 & 26.3 & 1.9 & 7 & 27.3 & 31.0 & 28.2 & 1.3 \\
\hline Dorsal fin length & 27.2 & 36 & 23.5 & 27.2 & 25.4 & 1.1 & 15 & 23.5 & 29.9 & 26.6 & 2.2 & 7 & 23.5 & 25.7 & 25.0 & 0.9 \\
\hline Pelvic fin length & 17.1 & 36 & 14.0 & 18.5 & 16.1 & 1.0 & 15 & 15.0 & 21.9 & 17.5 & 2.0 & 7 & 13.7 & 17.2 & 15.3 & 1.3 \\
\hline Pectoral fin length & 22.3 & 36 & 18.6 & 21.8 & 20.1 & 0.7 & 15 & 19.6 & 22.6 & 21.0 & 0.9 & 7 & 16.4 & 20.8 & 18.0 & 2.1 \\
\hline Head length & 23.2 & 36 & 23.1 & 25.3 & 24.0 & 0.6 & 15 & 23.2 & 26.4 & 24.6 & 0.8 & 7 & 25.8 & 27.4 & 26.7 & 0.6 \\
\hline \multicolumn{17}{|c|}{ Percents of Head Length } \\
\hline Snout length & 23.8 & 36 & 21.1 & 29.2 & 24.2 & 1.7 & 15 & 20.9 & 27.5 & 24.7 & 1.7 & 7 & 22.8 & 28.2 & 25.0 & 2.2 \\
\hline Upper Jaw length & 35.3 & 36 & 30.7 & 37.9 & 34.0 & 1.5 & 15 & 31.0 & 36.9 & 34.0 & 1.7 & 7 & 31.5 & 35.0 & 33.3 & 1.4 \\
\hline Horizontal orbit diameter & 36.9 & 36 & 34.0 & 40.5 & 36.9 & 1.7 & 15 & 35.0 & 40.9 & 37.2 & 1.7 & 7 & 34.9 & 40.7 & 37.5 & 1.9 \\
\hline Interorbital width & 32.6 & 36 & 29.0 & 35.1 & 32.5 & 1.5 & 15 & 29.4 & 34.1 & 31.4 & 1.3 & 7 & 29.1 & 34.6 & 31.1 & 1.7 \\
\hline
\end{tabular}

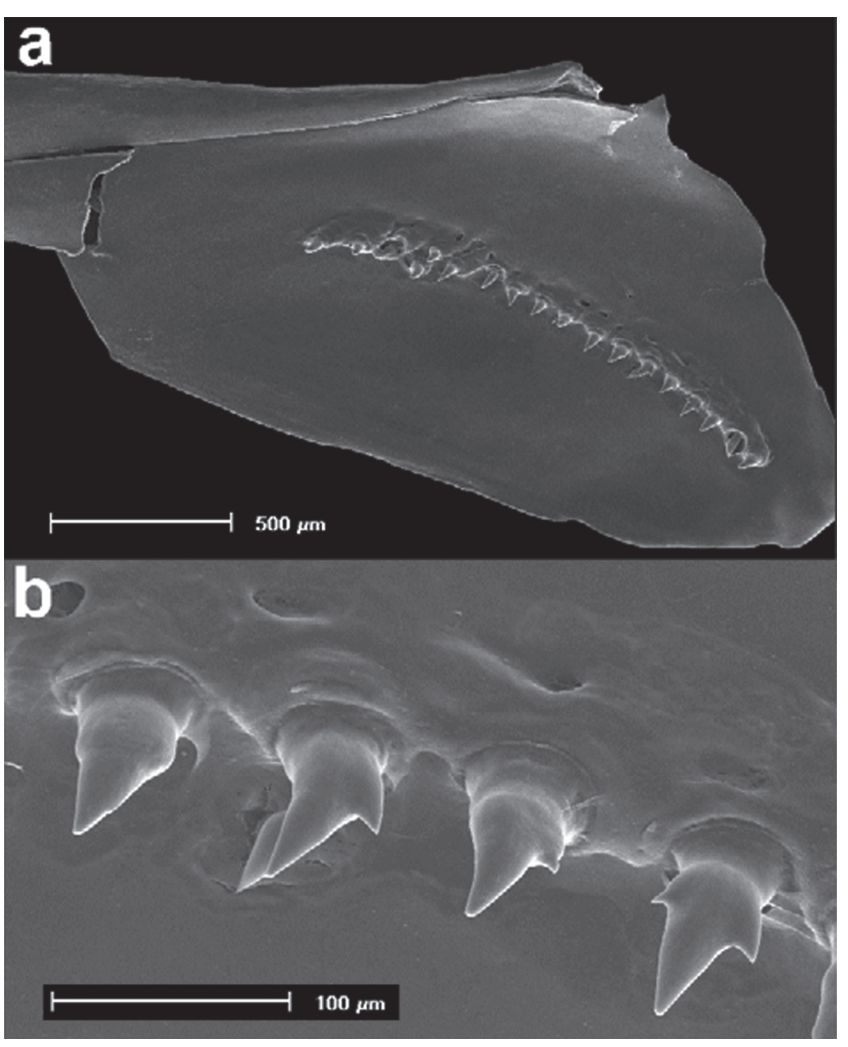

Fig. 3. Mesopterygoid of Odontostilbe weitzmani paratype, male (MCP 20337) ventral view: (a) mesopterygoid with teeth forming a row, (b) detailed image of the teeth of mesopterygoid with 1, 2 and 3 cusps. Scanning electron micrographs (SEM).
Supraneurals 4(3) without anterior and posterior projections, 5(3) upper gill rakers and 10(3) lower gill rakers ( 2 on hypobranchial). Upper gill rakers with $2-5$ denticles on anterolateral border, and 0-2 on posterolateral border, mainly on basal portion of upper gill rakers. Lower gill rakers with 3 or 6 denticles on anterolateral border, and none on posterolateral border. Gill raker at junction of ceratobranchial and epibranchial with 3-4 denticles on dorsolateral and 3 on ventrolateral borders (Fig. 4). Olfactory rosette slightly oval with 20(2) or 21(1) lamellae in left and right sides of central median raphe. Precaudal vertebrae 16(3); caudal vertebrae 18(3); total vertebrae 34(3).

Color in alcohol. Overall body coloration yellowish. Dorsal surface of head from snout to posterior limit of frontal darker with scattered light grey chromatophores. Darker in region of parietal and supraoccipital. Opercular apparatus and infraorbital region of beige silver color extending to cleithrum. Ventral region between pectoral and pelvic fins with a lighter yellow area. Humeral region with a darkened triangular area due to muscular hiatus of pseudotympanum. Scales of dorsal portion of body from supraoccipital to caudal peduncle with small dots dim-gray concentrated in posterior margin.Posterior region of pseudotympanum to caudal peduncle with a silvery lateral thin band above lateral line, top edge of chromatophores dim-gray forming a dark band reaching caudal spot. A conspicuous horizontally oval black caudal spot continued on base of middle caudal-fin rays (Fig. 1). 


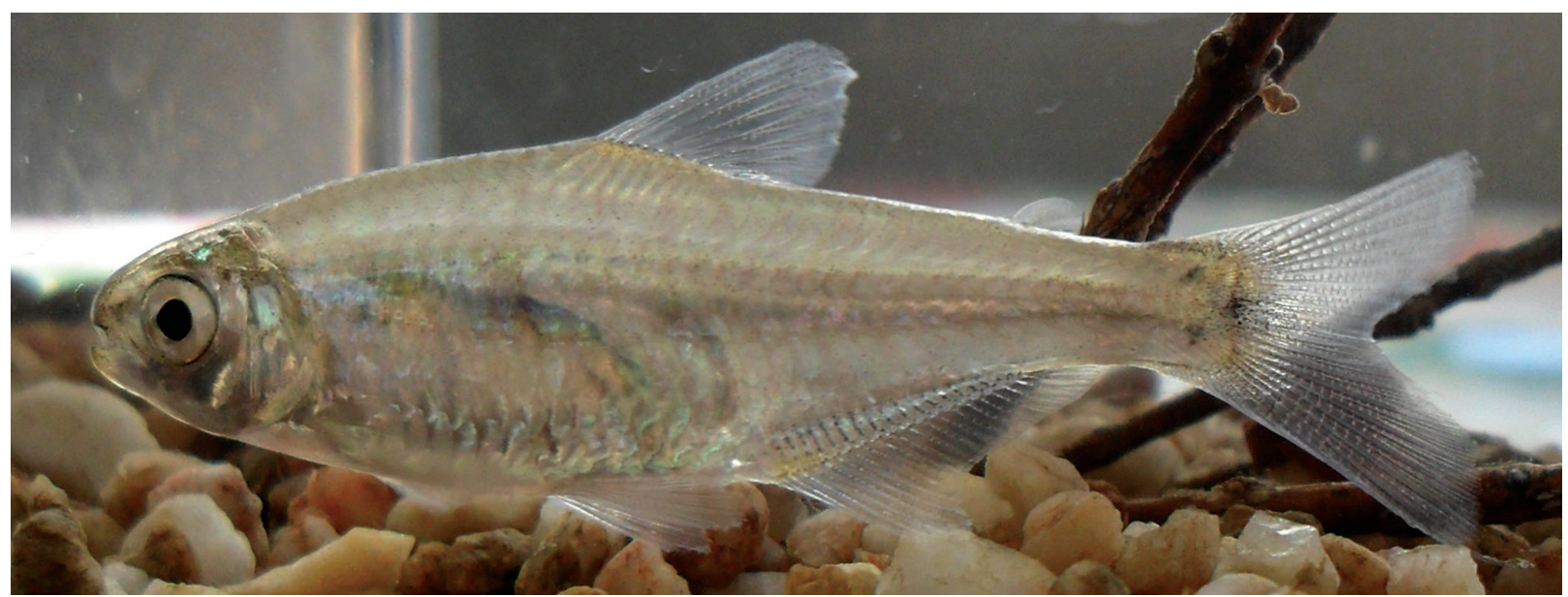

Fig. 4. Live specimen of Odontostilbe weitzmani collected in the Municipality of Carmo do Rio Claro, stream tributary of Ribeirão Itaci, rio Grande, upper rio Paraná, Minas Gerais, Brazil (not preserved, photo by Azevedo-Santos, V. M.).

Dorsal fin with scattered black chromatophores slightly darker and more numerous on mid-distal portion of dorsal fin, extending from second unbranched to eighth branched dorsal-fin rays. Pectoral and pelvic fins with dark grey chromatophores scattered mainly in unbranched rays. Anal fin with dark grey dots slightly scattered in all rays, concentrated in basal region. Adipose fin unpigmented.

Color in life. Caudal spot black, not reaching upper and lower margin of caudal peduncle and extending to base of central rays of caudal-fin, followed by silvery pigments in each lobe. Basal part of anal fin gold silvery. Body silvery, with scattered dark chromatophores on scales and fins (Fig. 5).

Sexual dimorphism. Mature males have second unbranched ray of dorsal fin and unbranched ray of pelvic fin slightly longer than remaining rays, differing from immature and females. Mature males with small hooks on pelvic and anal-fins rays. Pelvic-fin with small hooks in all branched rays, with 1 retrorse bony hook per segment on medioventral border of both lepidotrichia in median and distal length of pelvic-fin rays. Tip of bony hooks not reaching proximal border of segment of lepidotrichia where inserted. Anal-fin rays with one pair of small retrorse bony hooks per segment symmetrically arranged (exceptionally two pairs of hooks), present from last unbranched ray to fourth or seventh branched rays, decreasing in number posteriorly. Hooks mostly distributed along middle third of anal-fin ray length in posterolateral border. Distal tip of bony hooks not reaching proximal border of segment of lepidotrichia where inserted.

Males bearing gill gland (Fig. 4) similar in size and number of modified filaments (8) to those observed in other externally fertilized species of Cheirodontinae (Oliveira et al., 2012).

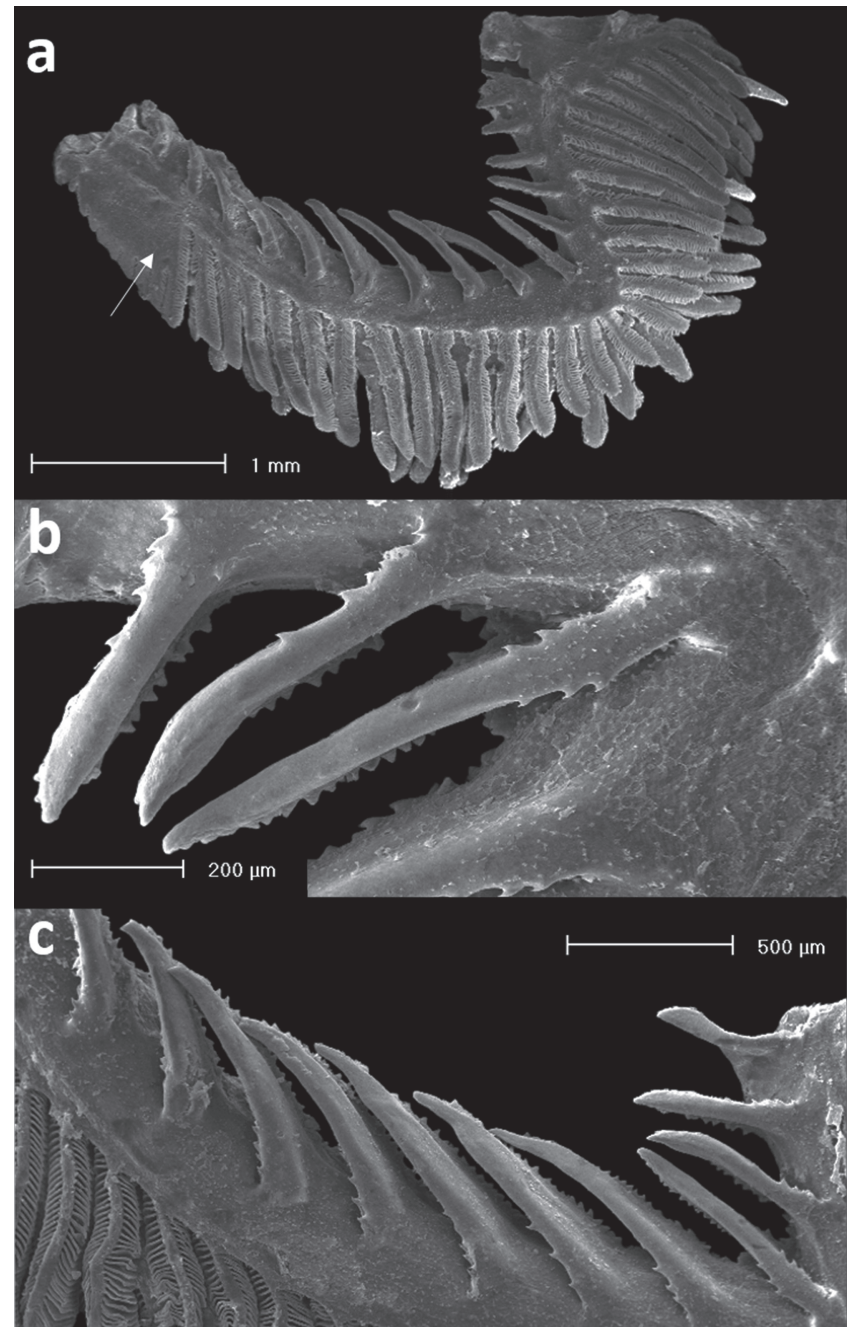

Fig. 5. First gill arch of Odontostilbe weitzmani: (a) left side, lateral view, showing gill gland (arrow) on anteriormost portion of lower branch of MCP 20337 male. In detail (b) gill rakers near the junction of ceratobranchial and epibranchial, and (c) gill rakers on lower branch of gill arch. Scanning electron micrographs (SEM). 
Geographic distribution: Odontostilbe weitzmani is known to inhabit tributaries of the upper rio Paraná, in the states of Goiás, Mato Grosso do Sul, Minas Gerais, and São Paulo, in Brazil (Fig. 6).

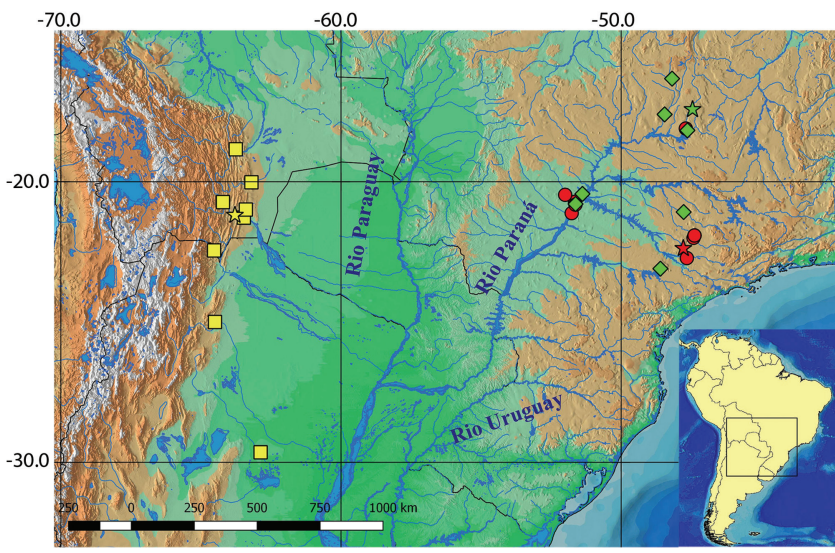

Fig. 6. Southern South America showing the distribution of Odontostilbe avanhandava (green diamonds), $O$. microcephala (yellow squares) and $O$. weitzmani (red circle). Type localities represented by star of respective colors.

Etymology. The specific epithet is named after Stanley $\mathrm{H}$. Weitzman, in recognition for his work on the systematics of Neotropical characiforms, particularly of the characid subfamily Cheirodontinae.

Conservation status. Odontostilbe weitzmani is abundant where it occurs. This species may be categorized as Least Concern (LC), according to the IUCN criteria for evaluation on threatening status, version 13 (IUCN, 2017).
Remarks. Besides the type specimens from the upper rio Paraná basin, on which we based the description, we analyzed additional lots of Odontostilbe weitzmani from two localities along the rio Corumbá, Goiás (MCP 25999 and MCP 26000 female, 55.1-56.8 mm SL). These specimens have the same number of cusps on premaxillary teeth, number of branched anal-fin rays and other morphometric characters as the type specimens, but can be differentiated in the length of caudal peduncle (9.9-11.8\% SL, mean 10.6\% SL vs. 10.8-14.5\% SL, mean $12.5 \% \mathrm{SL}$ in $O$. weitzmani type specimens) and body depth at dorsal-fin (35.0-37.1\% SL, mean 36.0, vs. 23.1-32.9\% SL, mean $27.9 \%$ SL in O. weitzmani type specimens). We suggest that this difference is related to the larger size of the individuals from rio Corumbá. Stretches of the rivers where these specimens were collected have been changed from lotic to lentic environments by the construction of hydroelectric power dams, and this may possibly influence the body size, body depth and caudal peduncle length of studied populations.

Several specimens of Odontostilbe weitzmani collected in the upper rio Paraná basin are found among the material that Eigenmann (1915) used to redescribe Odontostilbe microcephala (Fig. 1c; CM 6854a-c, now FMNH 131317; CM 6855a-p, now CAS 60508 and FMNH 57872), and since then, specimens of $O$. weitzmani from the upper rio Paraná have been erroneously identified as $O$. microcephala.

\section{Odontostilbe avanhandava, new species}

urn:1sid:zoobank.org:act:1 C963F22-25B9-4543-B0C0EFA18386A8B2

Figs. 7-9

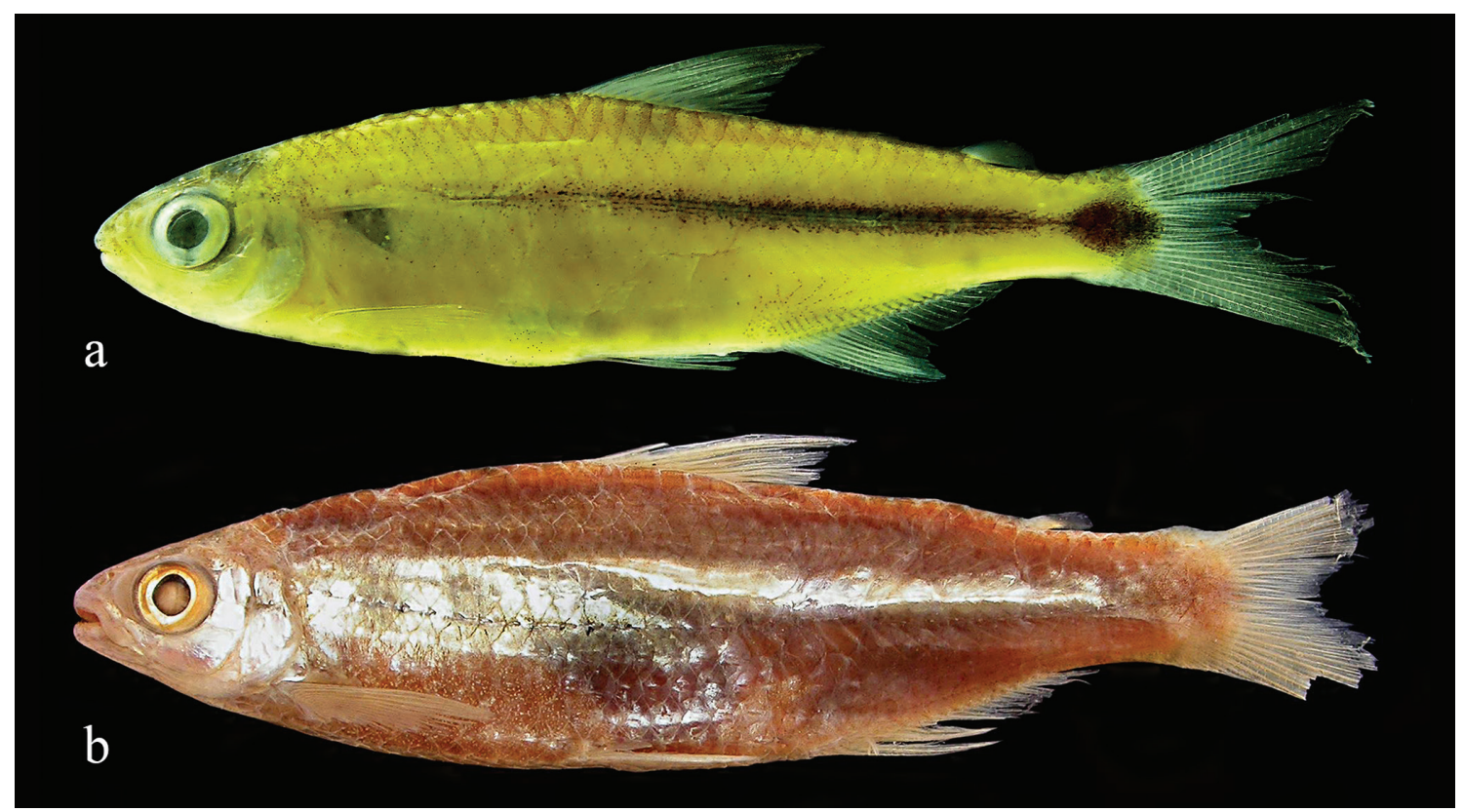

Fig. 7. Odontostilbe avanhandava: (a) holotype LIRP 3239, female, 48.7 mm SL; rio Paranaíba, Paracatu, Minas Gerais, Brazil. (b) paratype, FMNH 57871, male $62.1 \mathrm{~mm}$ SL, rio Tietê at Salto Avanhandava below the falls, São Paulo, Brazil; specimen reviewed by Eigenmann (1915). 
Odontostilbe microcephala non Eigenmann, 1907. -Eigenmann, 1915 [in part]: 94-95 (the largest specimen from CM 6854a-c (FMNH 57871) from rio Tietê at Salto Avanhandava above the falls, São Paulo, Brazil, upper rio Paraná basin).

Holotype. LIRP 3239, $48.7 \mathrm{~mm} \mathrm{SL}$, female, ribeirão da Batalha, farm Batalha (Pedro Quaresma), rio Paranaíba, Paracatu, Minas Gerais State, Brazil, $17^{\circ} 25^{\prime} 25^{\prime \prime} \mathrm{S}$ $47^{\circ} 27^{\prime} 11^{\prime \prime} \mathrm{W}, 27$ Apr 2002, C. A. A. Figueiredo \& E. S. S. Rego.

Paratypes. All from Brazil, upper rio Paraná basin. São Paulo State: FMNH 57871, 1, $62.1 \mathrm{~mm} \mathrm{SL}$, rio Tietê at Salto Avanhandava below the falls, 14 Sep 1908, J. Haseman [material reviewed by Eigenmann (1915)]. LIRP 00314, 2, 47.4-51.1 mm SL, rio Pardo, Ribeirão Preto, 15 Oct 1991, W. E. Alvear. MCP 12103, 1, $56.1 \mathrm{~mm} \mathrm{SL}$, Ilha Solteira, rio Paraná, Set 1965. MCP 26004, 2, 39.3-57.9 $\mathrm{mm}$ SL, rio Paranapanema, at Jurumirim dam reservoir, Itatinga, $23^{\circ} 06^{\prime} 00^{\prime \prime} \mathrm{S} 48^{\circ} 36^{\prime} 00^{\prime \prime} \mathrm{W}$, UNESP de Botucatu. Goiás State: MCP 26003, 1, $43.8 \mathrm{~mm}$ SL, rio do Peixe (tributary of rio Corumbá), rio Paranaíba, Caldas Novas, $17^{\circ} 36^{\prime} 00^{\prime \prime} \mathrm{S} 48^{\circ} 27^{\prime} 00^{\prime \prime} \mathrm{W}, 19$ Oct 1996, Nupelia. MCP $26002,1,57.7 \mathrm{~mm} \mathrm{SL}$, rio do Peixe, nex to mouth (tributary of rio Corumbá), rio Paranaíba, Caldas Novas, $17^{\circ} 36^{\prime} 00^{\prime \prime} \mathrm{S}$ $48^{\circ} 27^{\prime} 00^{\prime \prime}$ W, 21 Sep 1996, Nupelia. MNRJ 19718, 1, 54.2 $\mathrm{mm}$ SL, rio São Bento, a tributary of the left margin of the rio São Marcos, downstream of the future AHE Serra dam, Paranaíba basin, Divinópolis, $18^{\circ} 10^{\prime} 10^{\prime \prime S} 47^{\circ} 38^{\prime} 07^{\prime \prime} \mathrm{W}, 27$ Sep 1999, C. A. Figueiredo, F. A. Bockmann \& A. P. R. Pires. MZUSP 80112, 2, 66.4-77.7 mm SL, Ensecadeira da Usina Hidroeletrica de Corumbá IV, rio Corumbá, Luziânia, H. L. R. Silva. Mato Grosso do Sul State: MCP $12101,1,30.2 \mathrm{~mm} \mathrm{SL}$, lakes along of the margin of rio Paraná, in front of Jupiá, 11-23 Sep 1964.

Diagnosis. Odontostilbe avanhandava differs from its congeners, except of $O$. weitzmani, by the presence of mesopterygoid teeth, grouped on median portion forming a continuous row, covering half of mesopterygoid bone (vs. absent). Odontostilbe avanhandava is distinguished from $O$. weitzmani by the presence de 11-12 lamellae in left and right sides of central median raphe of olfactory rosette (vs. 20-21) and from all species of the genus, except $O$. fugitiva, $O$. splendida, $O$. parecis, and $O$. pao by the presence of teeth with 9 or 11 cusps in the premaxilla, mostly 9, occasionally 7 cusps (vs. 3-7 cusps; teeth with 9 or 11 cusps always absent). Odontostilbe avanhandava is distinguished from O. fugitiva, O. splendida, and $O$. pao by the subterminal mouth (vs. terminal mouth); additionally from $O$. parecis and $O$. fugitiva by the presence of 16-18 branched anal-fin rays, mostly 17 (vs. 20-21 in O. parecis and 19-24, mostly 21-22 in $O$. fugitiva); from $O$. splendida by the anterior position of the adipose fin, positioned at vertical through last analfin ray insertion ( $v s$. at vertical through last 2 nd or $3 \mathrm{rd}$ anal-fin ray insertions); from $O$. pao by the presence of 5 scale rows between lateral line and dorsal-fin origin ( $v s$. 6-7, mostly 7).

Description. Morphometric data on Tab. 2. Body elongate and slightly compressed (Fig. 7). Greatest body depth at vertical through dorsal-fin origin. Snout elongated and round. Dorsal profile of head convex from snout to posterior margin of frontal bone, slightly concave from there to distal tip of supraoccipital bone. Predorsal profile slightly convex from posterior end of supraoccipital to dorsal-fin origin. Dorsal-fin origin located at midlength of SL. Body profile in base of dorsal fin straight and slightly convex from that point to origin of adipose fin. Body profile between adipose-fin base and dorsal procurrent caudalfin rays slightly concave. Ventral profile of head slightly convex from snout to origin of pelvic fins and convex from there to origin of anal fin. Body profile along base of anal fin straight or slightly convex. Ventral profile of caudal peduncle slightly concave. Caudal peduncle slightly longer than deep.

Tab. 2. Morphometric data for Odontostilbe avanhandava, number of individuals $(\mathrm{N})$, mean, minimum (min), maximum (max) and standard deviation (SD) include values of holotype (female).

\begin{tabular}{|c|c|c|c|c|c|c|}
\hline & Holotype & $\mathrm{N}$ & Min & Max & Mean & SD \\
\hline Standard length (mm) & 48.7 & 14 & 30.2 & 70.7 & 53.0 & - \\
\hline \multicolumn{7}{|c|}{ Percents of Standard Length } \\
\hline Snout to anal-fin origin & 67.1 & 14 & 66.9 & 71.6 & 68.3 & 1.4 \\
\hline Snout to dorsal-fin origin & 47.2 & 14 & 46.2 & 50.7 & 48.3 & 1.4 \\
\hline Snout to pelvic-fin origin & 47.2 & 14 & 46.5 & 50.8 & 48.3 & 1.3 \\
\hline Snout to pectoral-fin origin & 21.1 & 14 & 18.7 & 24.2 & 21.6 & 1.8 \\
\hline Dorsal to caudal-fin origin & 49.2 & 14 & 48.9 & 53.5 & 51.3 & 1.6 \\
\hline Orbit to dorsal-fin origin & 32.4 & 14 & 31.8 & 38.0 & 34.9 & 1.7 \\
\hline Anal-fin base length & 18.2 & 14 & 17.4 & 22.4 & 20.0 & 1.5 \\
\hline Length of caudal peduncle & 12.4 & 14 & 10.3 & 13.2 & 12.1 & 0.9 \\
\hline Depth of caudal peduncle & 15.9 & 14 & 9.7 & 15.9 & 11.1 & 1.5 \\
\hline Body depth at dorsal-fin & 25.4 & 14 & 25.4 & 32.9 & 29.2 & 2.3 \\
\hline Dorsal-fin length & 24.2 & 14 & 21.6 & 26.5 & 24.2 & 1.3 \\
\hline Pelvic-fin length & 16.5 & 14 & 14.4 & 17.7 & 16.1 & 0.9 \\
\hline Pectoral-fin length & 19.5 & 14 & 17.9 & 20.9 & 19.1 & 1.0 \\
\hline Head length & 22.2 & 14 & 21.3 & 24.0 & 22.5 & 0.8 \\
\hline \multicolumn{7}{|c|}{ Percents of Head Length } \\
\hline Snout length & 25.5 & 14 & 23.3 & 28.4 & 25.5 & 1.4 \\
\hline Upper Jaw length & 31.0 & 14 & 30.8 & 36.3 & 32.8 & 1.7 \\
\hline Horizontal orbit diameter & 38.3 & 14 & 31.0 & 39.7 & 35.5 & 2.4 \\
\hline Interorbital width & 34.9 & 14 & 30.9 & 36.1 & 33.6 & 1.9 \\
\hline
\end{tabular}

Head small relative to body length, 21.3-24.0\% SL. Mouth subterminal, opening oriented forward and somewhat ventrally, in which upper jaw and snout clearly extends beyond lower jaw. Maxilla posteroventrally angled, posterior end surpassing vertical through anterior border of eye and 
surpassing horizontal through ventral border of eye. Two or 3 maxillary teeth, with 7-9 [mostly 9] cusps nearly of equal size. Premaxilla with a single row of 5-6 teeth slightly inclined to inside mouth (Fig. 8), bearing 7-11 [mostly 9] cusps nearly of equal size. Dentary with 7 or 8 teeth, anterior 6 teeth larger, bearing 7 cusps nearly equal in size, followed posteriorly by 1 or 2 smaller conical teeth, rarely tricuspidate. Dentary teeth inclined anteriorly. Presence of mesopterygoid teeth, grouped on median portion of bone forming a continuous row, covering half-length of ventral surface of mesopterygoid.

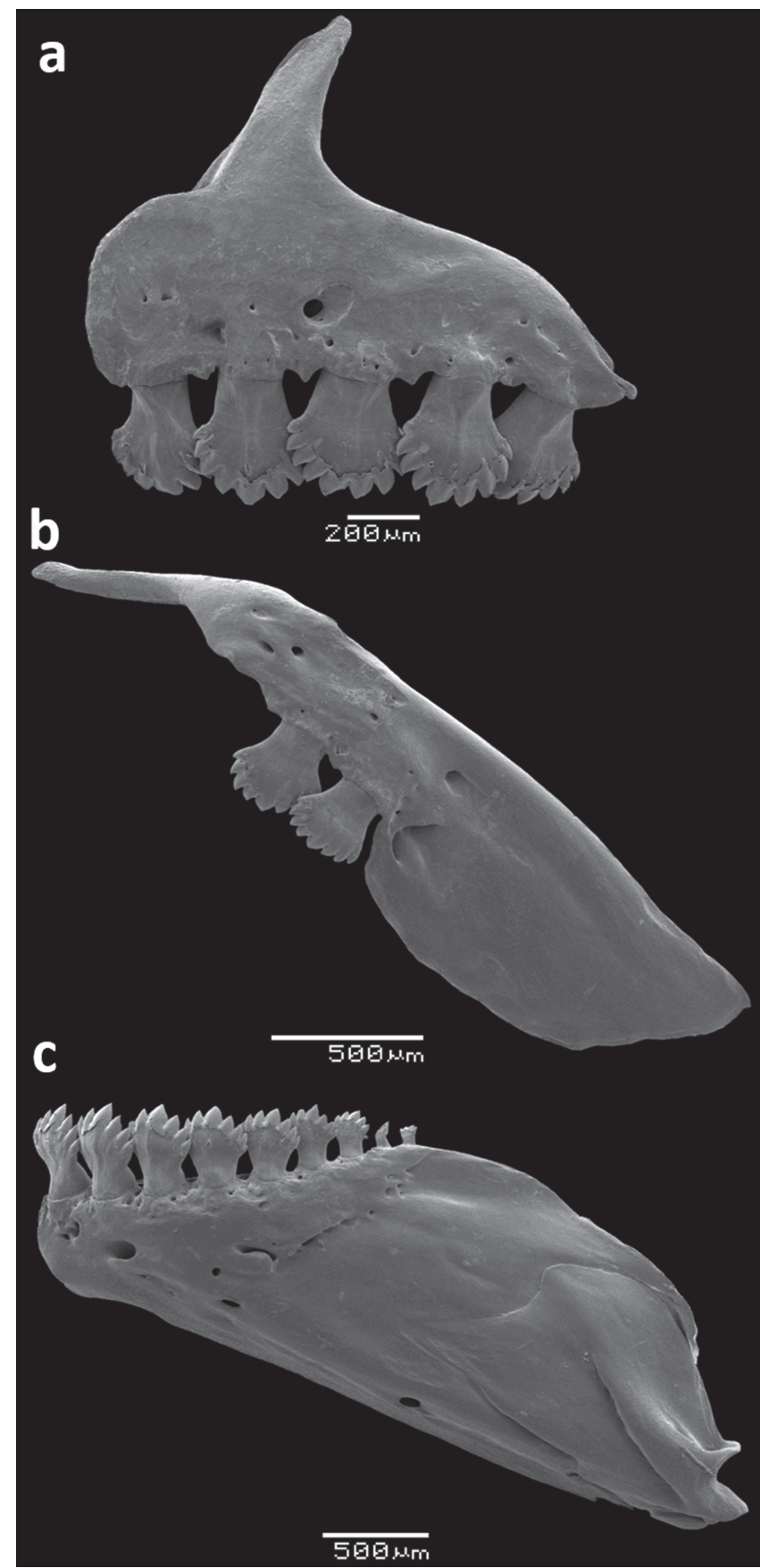

Fig. 8. Dentition of Odontostilbe avanhandava, MCP 26004, paratype: (a) premaxilla, (b) maxilla, and (c) dentary, left side, lateral view. Scanning electron micrographs (SEM).
Dorsal-fin rays ii,9(14) in all examined specimens. Dorsal-fin origin at vertical of pelvic-fin insertion. Profile of distal margin of dorsal fin slightly concave. First unbranched dorsal-fin ray less that half-length of second, following branched rays gradually decreasing in size posteriorly. Presence of small ossification associated with first proximal dorsal-fin radial (character 124, described by Zanata, Vari, 2005). First unbranched ray of dorsalfin inserted in first pterygiophore and last two branched rays inserted in tenth pterygiophore. Proximal radial of first pterygiophore in contact with neural spine of eleventh precaudal vertebra. Dorsal fin with medial radial fused with distal radial from first to fourth pterygiophore and individualized from fifth to tenth pterygiophore. Proximal radial of first to ninth pterygiophores with lateral projections.

Adipose-fin origin posterior to vertical through base of last anal-fin ray. Unbranched anal-fin rays iv(1); branched anal-fin rays $16(4), 17(8), 18(2)$, with two rows of scales covering base of anterior 6 branched rays. Anal-fin origin posterior to vertical through base of last ray of dorsal fin. Profile of distal margin of anal fin concave. Anal fin with all unbranched rays associated with first pterygiophore, except last unbranched ray associated with second pterygiophore. Medial radial fused with distal radial from first to fifth pterygiophores, visible from that point to last pterygiophore. Proximal radial of first pterygiophore in contact with hemal spine of first caudal vertebra.

Pectoral fin rays i(14), 11(2), 12(1), 13(5), 14(4), or 15(2). First pectoral-fin ray reaching anterior tip of pelvic bone. Pelvic fin i,7(14) rays; insertion located approximately at vertical through origin of dorsal fin. In mature males, first unbranched ray prolonged in filament, usually surpassing origin of anal fin. Principal caudal fin rays $19(14)$. Procurrent caudal-fin rays: dorsal $7(3), 8(9)$, $9(1)$, or $11(1)$ rays and ventral with $6(2), 7(4), 8(3), 9(4)$, or $10(1)$ rays.

Cycloid scales; pored scales on lateral line 36(1), 37(4), 38 (4), or 39(2). Predorsal scales arranged in a regular series with 11(2) or 12(6) scales; scale rows between lateral line and dorsal line origin 5(14); scales rows between lateral line and pelvic-fin origin 4(14); scale rows around caudal peduncle 14(11)

Supraneurals independent, elongate, rod-like, 5(1). Precaudal vertebrae 17; caudal vertebrae 19; total vertebrae 36. Upper gill rakers 6, lower gill rakers 12(2 on hypobranchial). Upper gill rakers with 6-8 denticles on anterolateral border, and 0-2 denticles on posterolateral border. Lower gill rakers with 7-12 denticles on anterolateral border, and 0-1 denticles on posterolateral border. Gill raker inserted on junction of ceratobranchial and epibranchial with 10 denticles on ventrolateral and 3 on dorsolateral borders (Fig. 9). Olfactory rosette of Odontostilbe avanhandava is more or less circular in shape and consists of 11(1) or 12(1) lamellae in left and right sides of central median raphe. 


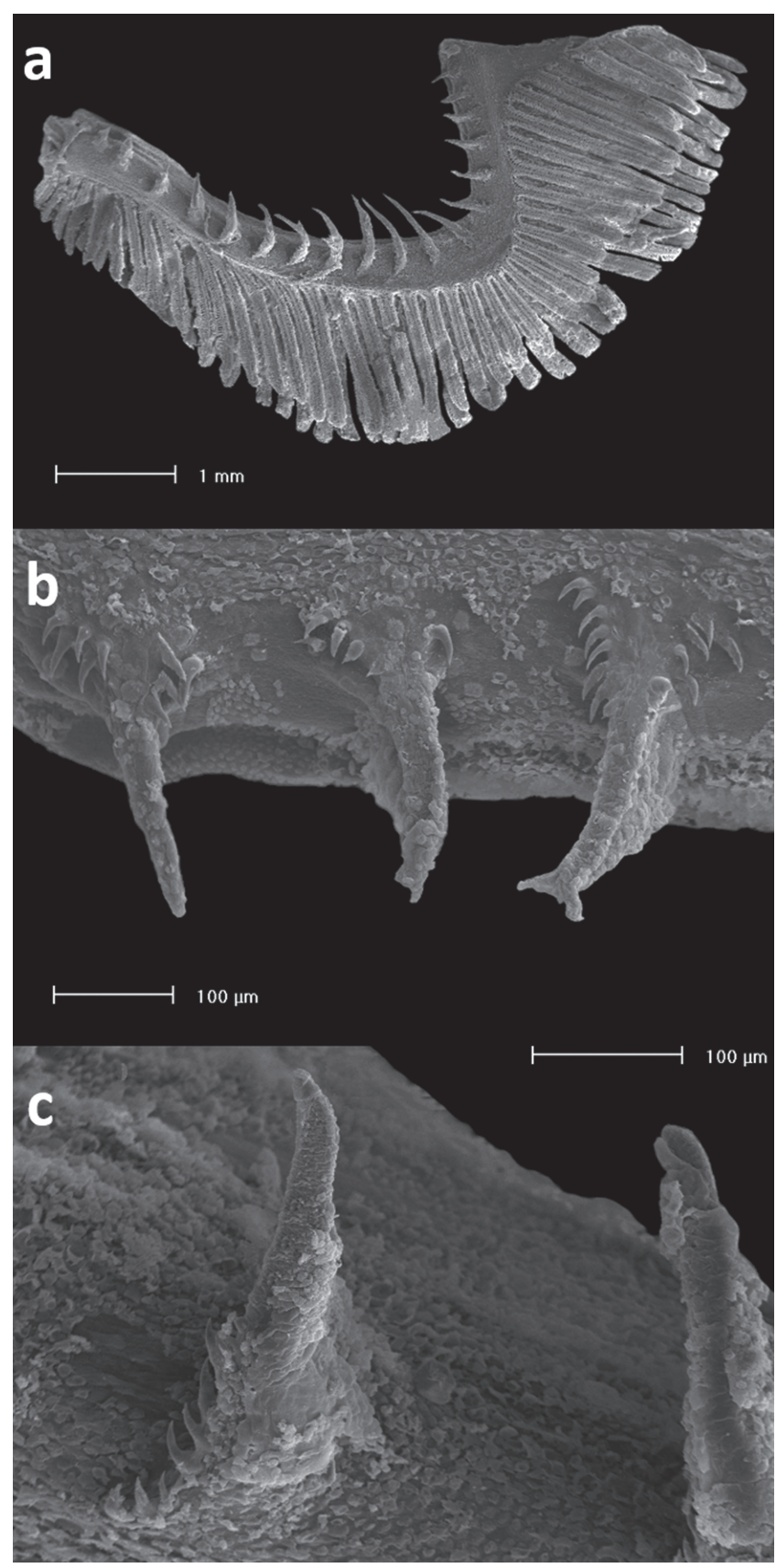

Fig. 9. (a) First gill arch of Odontostilbe avanhandava, MCP 26004, paratype, left side, lateral view. In detail (b) gill rakers on upper branchial branch, and (c) gill rakers on lower branchial branch. Scanning electron micrographs (SEM).

Color in alcohol. Overall body coloration yellowish. Dorsal surface of head from snout to posterior limit of frontal with chromatophores scattered giving a dark yellow coloration. Dark red chromatophores noticeably more concentrated in region of parietal and supraoccipital. Opercular apparatus and infraorbital region silver beige. Branchiostegal rays silver beige. Ventral region between pectoral and pelvic fins with a lighter yellow area. Humeral region with a darkened triangular area due to muscular hiatus of pseudotympanum.
Scales of dorsal portion of body from supraoccipital to caudal peduncle with small dark dots concentrated on posterior margin. Region posterior of pseudotympanum to caudal peduncle with thin silvery band, dorsal and ventral edges of gray color, chromatophores forming a black band reaching caudal spot. A conspicuous oval horizontally black caudal spot overlapping base of middle caudal fin rays.

Dorsal fin with scattered black chromatophores slightly darker and more numerous on mid-distal portion of dorsal fin, extending from first unbranched dorsal-fin ray to ninth branched fin ray. Pectoral and pelvic fins hyaline. Anal fin with sparse dark dots scattered over all rays, more concentrated in the basal region. Adipose fin unpigmented.

Sexual dimorphism. Mature males with small hooks on pelvic and anal fins. Pelvic-fin with small hooks in all branched rays, with one retrorse bony hook per segment, on mesoventral border of both lepidotrichia in median and distal portions of pelvic fin. Tip of bony hooks not reaching proximal border of segment of lepidotrichia where inserted. Anal-fin rays with one pair of small retrorse bony hooks per segment symmetrically placed, on last unbranched ray and first to fourth branched rays, decreasing in number posteriorly. Bony hooks on median portion of posterior branch (never on anterior branch). Tip of bony hooks not reaching proximal border of segment of lepidotrichia where inserted.

Geographic distribution. Odontostilbe avanhandava is known to inhabit tributaries of the upper rio Paraná basin, in the states of Mato Grosso do Sul, Goiás, Minas Gerais, and São Paulo, Brazil (Fig. 6).

Etymology. The epithet avanhandava, refers to the "Salto do Avanhandava" falls of the rio Tietê, the locality of collection of the oldest known specimen, collected by John D. Haseman in 1908. The toponym Ava - Nhandava means: "Man who speaks the Nhandeva dialect". The "Salto do Avanhandava" does not exist anymore and was flooded by the Nova Avanhandava Hydroelectric Power Dam. A name in apposition.

Conservation status. Odontostilbe avanhandava presents the same distribution of Odontostilbe weitzmani. This species is not abundant in scientific collections, but represents a wide distribution in upper rio Paraná basin. Odontostilbe avanhandava may be categorized as Least Concern (LC), according to the IUCN criteria for evaluation on threatening status, version 13 (IUCN, 2017).

Remarks. A specimen of Odontostilbe avanhandava collected in the upper rio Paraná basin was found in the material used by Eigenmann (1915) to redescribe $O$. microcephala (FMNH 57871), and since then, specimens of $O$. avanhandava from the upper rio Paraná have been identified as $O$. microcephala. 


\section{Odontostilbe microcephala Eigenmann, 1907}

Figs. 10-12

Odontostilbe microcephalus Eigenmann, in Eigenmann, Ogle, 1907:10 (original description; type locality: rio Pilcomayo, Bolivia). -Fowler, 1940:61-62 (color description in alcohol; collected río Pilcomayo, tributary of the río Paraguay, Villa Montes, Department of Tarija).

Odontostilbe microcephala. -Eigenmann, 1910:429 (cited, habitat: Pilcomayo).-Eigenmann, 1915 (in part): 94-95 (type and paratype from río Pilcomayo, Bolivia); 94 (figure maxilla, premaxilla and mandible). -Ringuelet et al., 1967: 94 (key diagnosed), 95-96 (brief description).-Géry, 1972:70-71 (comparative material). -Géry, 1977:558 (key).-Casciotta et al., 1992 (comparative material). -Malabarba, 2003:218 (distribution: rio Pilcomayo basin, Bolivia). -Bührnheim, Malabarba, 2006:172 (comparative material). -Bührnheim, Malabarba, 2007:5 (comparative material). -Miquelarena et al., 2008: 57-58 (Key), 82-83 (description, distribution).-Mirande, Aguilera, 2009:181 (description, distribution) -Mirande, 2010:557 (comparative material).

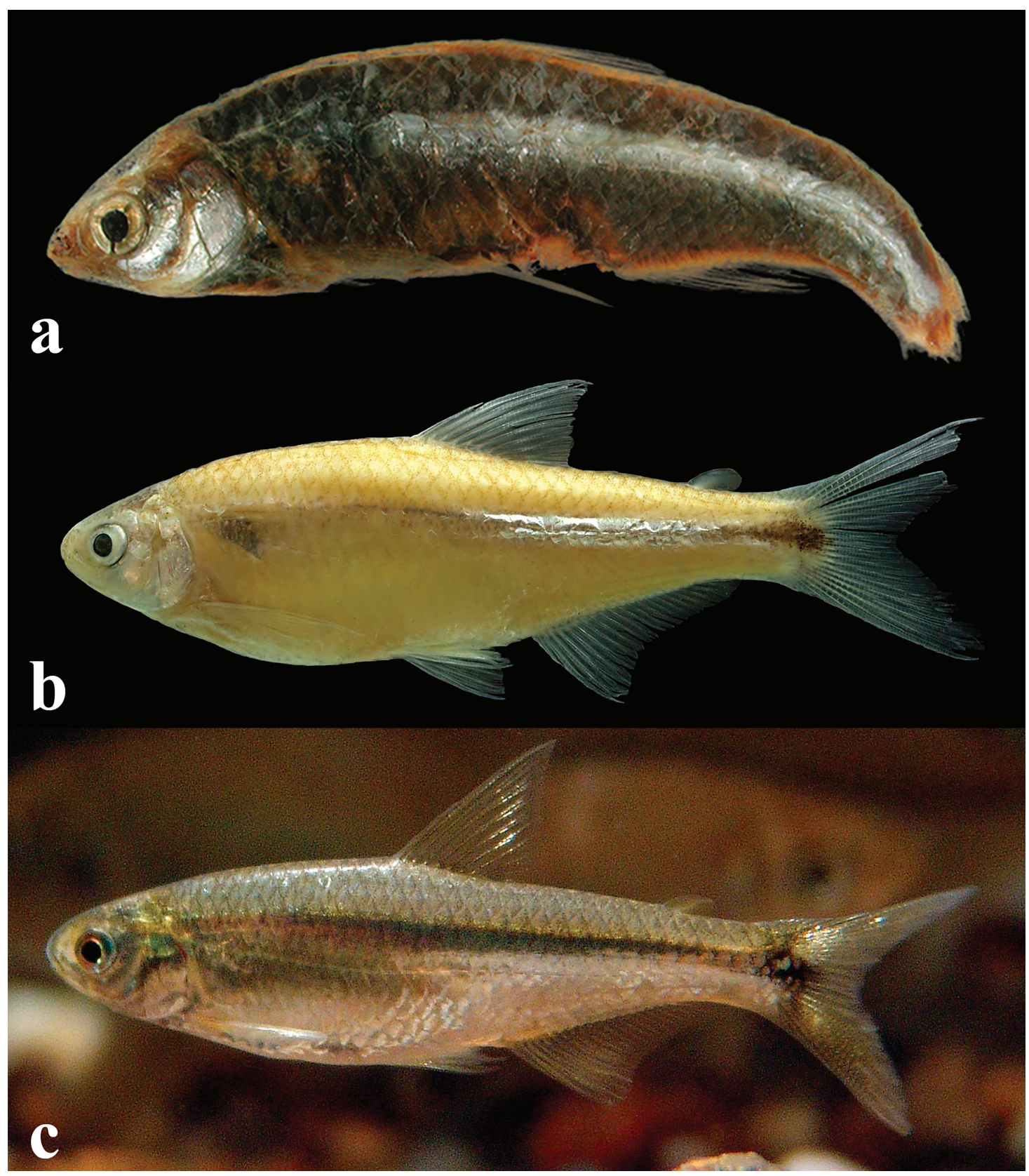

Fig. 10. Odontostilbe microcephala: (a) holotype CAS 59790, male $32.7 \mathrm{~mm}$ SL, río Pilcomayo, Bolivia, tributary of río Paraguay (photo by The California Academy of Sciences - Ichthyology Section); (b) MCP 38310, female, 45.6 mm SL, arheic basin of río Horcones, Salta, Rosario de la Frontera, Argentina; (c) male, río Salí, in Tucumán, Argentina (not preserved, photo by Gaston Aguilera). 
Diagnosis. Odontostilbe microcephala is distinguished from all species of the genus by the subterminal mouth ( $v s$. terminal mouth, except in $O$ dierythrura, O. euspilurus, and $O$. avanhandava); usually 10 gill rakers on upper branch and 14-15 on lower branch (vs. 11-12 on lower branch in $O$. dierythrura, 5-6 on upper branch and 9-10 on lower branch in O. euspilurus). Odontostilbe microcephala differs from $O$. avanhandava in the horizontal orbit diameter (24.6-32.8 \% HL, mean $28.7 \%$ vs. $31.0-39.7 \%$ HL, mean $35.5 \%$ ), number of scales rows between lateral line and dorsal-fin origin (6vs. 5 in O. avanhandava). Odontostilbe microcephala further differs from $O$. weitzmani by the presence of 12-13 lamellae in left and right sides of central median raphe of olfactory rosette with (vs. 20-21) and by the horizontal orbit diameter $(24.6-32.8 \% \mathrm{HL}$, mean $28.7 \%$ vs. 34.0-40.9\% HL, mean $37.0 \%$ ). Additionally $O$. microcephala is distinguished from $O$. avanhandava and $O$. weitzmani by the absence of mesopterygoid teeth ( $v s$. presence).

Description. Morphometric data in Tab. 3. Body relatively elongate and compressed (Fig. 10). Greatest body depth at or immediately anterior to dorsal-fin origin. Dorsal profile of head relatively convex from snout to vertical through posterior border of nares, straight or slightly convex from that point to rear of supraoccipital spine. Predorsal profile of body slightly convex from posterior end of supraoccipital to dorsal-fin origin located at vertical of midlength of standard length, dorsal-fin base straight to slightly convex. Dorsal profile of body between last dorsalfin ray and adipose-fin slightly convex, slightly concave from that point to caudal-fin origin. Caudal peduncle slightly longer than deep. Ventral profile of head slightly convex from mouth to pectoral-fin origin; convex from that point to ventral-fin origin, with an obtuse angle in the prepelvic region. Ventral profile straight from pelvic-fin origin to anal-fin origin. Anal-fin base straight to slightly concave. Caudal-peduncle ventral profile straight.

Head small. Mouth subterminal, upper jaw and snout extending anteriorly beyond lower jaw tip. Maxilla short, positioned obliquely at angle inferior of 45 degrees relative to body axis. Premaxillary dentition in single row with 5 teeth, slightly inclined to inside mouth, bearing 7 cusps, exceptionally 9; central cusp slightly longer and wider than lateral cusps. Maxilla with two teeth bearing 7 cusps, similar in shape to premaxillary teeth. Dentary with 8 or 9 teeth, anterior 7 teeth larger, bearing 7 cusps, with central cusp slightly longer and wider than lateral cusps, followed posteriorly by 1 or 2 smaller and conical teeth. Dentary teeth inclined anteriorly (Fig. 11).

Tab. 3. Morphometric data for Odontostilbe microcephala. Males range, females range, unsexed range, number of individuals $(\mathrm{N})$, mean, minimum (min), maximum (max) and standard deviation (SD) include values of the paratype CAS 59791 and Standard length of holotype CAS 59790 (male).

\begin{tabular}{|c|c|c|c|c|c|c|c|c|c|c|c|c|}
\hline & \multirow{2}{*}{$\begin{array}{c}\text { Holotype } \\
\text { CAS59790 }\end{array}$} & \multirow{2}{*}{$\begin{array}{c}\text { Paratype } \\
\text { CAS59791 }\end{array}$} & \multicolumn{5}{|c|}{ Females } & \multicolumn{5}{|c|}{ Males } \\
\hline & & & $\mathrm{N}$ & Min & Max & Mean & $\mathrm{SD}$ & $\mathrm{N}$ & Min & $\operatorname{Max}$ & Mean & $\mathrm{SD}$ \\
\hline Standard length $(\mathrm{mm})$ & 32.7 & 33.7 & 39 & 29.7 & 52.0 & 38.8 & - & 22 & 30.4 & 43.6 & 36.4 & - \\
\hline \multicolumn{13}{|c|}{ Percents of Standard Length } \\
\hline Snout to anal-fin origin & & 67.1 & 36 & 61.6 & 69.1 & 64.2 & 1.4 & 18 & 61.7 & 64.7 & 63.4 & 1.0 \\
\hline Snout to dorsal-fin origin & & 48.1 & 36 & 45.5 & 50.8 & 48.3 & 1.1 & 18 & 45.7 & 50.1 & 48.0 & 1.0 \\
\hline Snout to pelvic-fin origin & & 446.0 & 36 & 42.7 & 48.8 & 45.7 & 1.2 & 18 & 44.0 & 49.2 & 45.9 & 1.4 \\
\hline Snout to pectoral-fin origin & & 21.1 & 36 & 20.1 & 23.0 & 21.7 & 0.7 & 18 & 20.7 & 23.8 & 22.3 & 0.9 \\
\hline Dorsal to caudal-fin origin & & 50.5 & 36 & 48.0 & 56.8 & 52.1 & 1.9 & 18 & 48.7 & 55.0 & 52.2 & 1.7 \\
\hline Orbit to dorsal-fin origin & & 39.5 & 36 & 33.7 & 39.6 & 37.1 & 1.4 & 18 & 32.8 & 38.6 & 36.2 & 1.4 \\
\hline Anal fin base length & & 23.2 & 31 & 20.1 & 24.4 & 21.9 & 1.0 & 18 & 20.2 & 25.2 & 22.6 & 1.2 \\
\hline Peduncle length & & 14.9 & 32 & 11.5 & 16.9 & 14.4 & 1.2 & 18 & 11.2 & 16.2 & 14.0 & 1.4 \\
\hline Peduncle depth & & 10.4 & 32 & 9.8 & 12.5 & 10.8 & 0.7 & 18 & 8.6 & 11.7 & 10.5 & 0.9 \\
\hline Body depth at dorsal fin & & & 34 & 24.3 & 34.0 & 28.2 & 2.4 & 18 & 24.7 & 30.7 & 27.5 & 2.0 \\
\hline Dorsal fin length & & & 27 & 22.8 & 28.1 & 24.6 & 1.2 & 17 & 23.8 & 32.9 & 27.2 & 3.1 \\
\hline Pelvic fin length & & & 29 & 13.9 & 17.4 & 16.0 & 0.9 & 18 & 16.3 & 21.4 & 18.3 & 1.7 \\
\hline Pectoral fin length & & & 29 & 17.3 & 25.9 & 20.2 & 1.6 & 18 & 17.8 & 23.2 & 20.9 & 1.4 \\
\hline Head length & & 23.4 & 36 & 20.5 & 23.9 & 22.4 & 0.8 & 18 & 21.2 & 23.6 & 22.7 & 0.6 \\
\hline \multicolumn{13}{|c|}{ Percents of Head Length } \\
\hline Snout length & & 22.8 & 36 & 18.8 & 24.8 & 22.6 & 1.4 & 18 & 20.1 & 25.1 & 23.2 & 1.4 \\
\hline Upper Jaw length & & 30.4 & 33 & 29.0 & 35.7 & 31.5 & 1.9 & 18 & 29.6 & 35.8 & 32.1 & 2.0 \\
\hline Horizontal orbit diameter & & 25.3 & 36 & 25.3 & 32.8 & 28.6 & 1.9 & 18 & 24.6 & 31.8 & 28.8 & 2.0 \\
\hline Interorbital width & & 30.4 & 36 & 28.4 & 35.6 & 32.4 & 2.0 & 18 & 29.4 & 35.5 & 32.0 & 1.7 \\
\hline
\end{tabular}


Dorsal-fin rays ii,9(23). Dorsal-fin origin posterior to vertical through pelvic-fin insertion. Profile of distal margin of dorsal fin slightly concave. First unbranched dorsal-fin ray about half-length of second ray, following branched rays gradually decreasing in size posteriorly. In mature males, second unbranched ray is elongated in filament; its length three times longer than first unbranched ray, reaching origin of adipose fin in some specimens (Fig. 12b). First unbranched ray of dorsal fin inserted in first pterygiophore and last 2 branched rays inserted in tenth pterygiophore. Proximal radial of first pterygiophore in contact with neural spine of 11 th or 12 th precaudal vertebrae. Dorsal fin with medial radial fused with distal radial from first to fifth pterygiophore and not fused from sixth to ninth pterygiophore. All proximal radials with lateral projections. Origin of adipose fin anterior to vertical through base of last anal-fin ray.

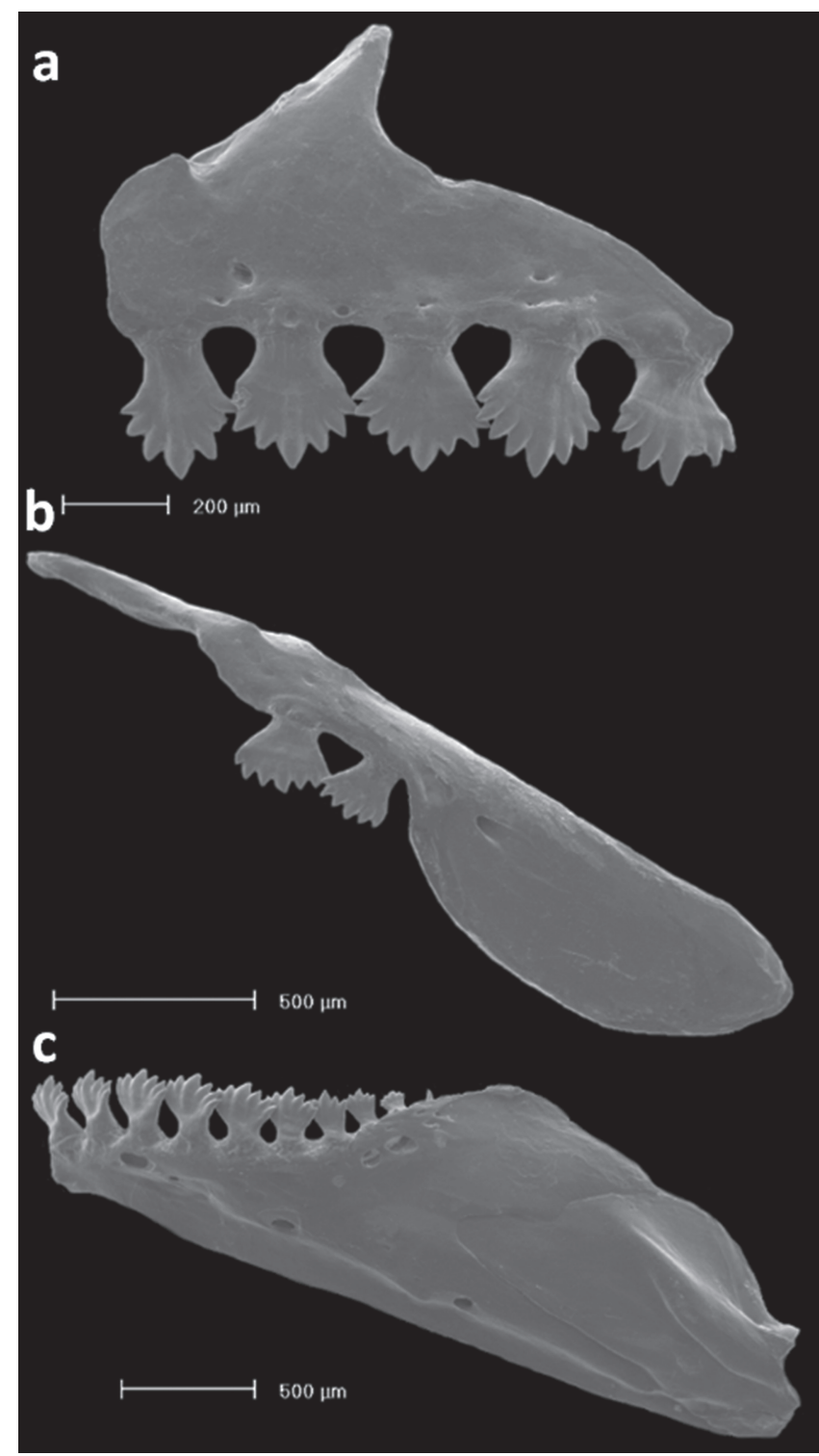

Fig. 11. Dentition of Odontostilbe microcephala, paratype USNM 32473, left side, lateral view: (a) premaxilla, (b) maxilla, and (c) dentary. Scanning electron micrographs (SEM).
Unbranched anal-fin rays iv(1), or v(3); branched analfin rays 16(1), 17(6), 18(8), 19(7), with two rows of scales covering base of anterior 5 branched rays. Anal-fin origin posterior to vertical through base of last dorsal-fin ray. Profile of distal margin of anal fin concave. Anal fin with 20 pterygiophores, anterior 3 or 4 unbranched rays associated with first pterygiophore. First 4 to 7 pterygiophores with medial radial fused with distal, not fused from that point to last pterygiophore. Proximal radial of first pterygiophore in contact with hemal spine of first caudal vertebra.

Pectoral-fin rays i(23), 10(1), 11(11), 12(9), or 13(2). Longest pectoral-fin ray reaching anterior edge of pelvic bone, reaching origin of pelvic fin in mature males. Pelvic fin i,7(23) rays; fin insertion slightly anterior to vertical through origin of dorsal fin. In mature males, first unbranched ray prolonged in filament, usually surpassing origin of anal fin. Elongated thin hooks present on all branched pelvic-fin rays in mature males. Principal caudalfin rays 19(23). Procurrent caudal-fin rays: dorsal 9(5), 10(9), 11(5), or 12(3) and ventral 6(1), 7(1), 8(7), 9(10), or $10(3)$.

Cycloid scales; lateral line with 35(3), 36(4), or 37(8) pored scales. Predorsal scales arranged in regular series with 11(4), 12(5), or 13(1) scales; scale rows between lateral line and dorsal-fin origin 6(15); scale rows between lateral line and pelvic-fin origin 4(14), exceptionally 3(1); scale rows around caudal peduncle 14(23).

Supraneurals 5(11) or 6(3). Precaudal vertebrae 17(4) or 18(5); caudal vertebrae 17(4), 18(4), or 19(1); total vertebrae 34(1), 35(6), 36(1), or 37(1). Upper gill rakers 10 , lower 14-15 (2 on hypobranchial). Upper gill rakers with 3 or 4 denticles on anterolateral border, and 2 or 3 denticles on posterolateral border. Lower gill rakers with 4 denticles on anterolateral border, and 1 or 2 denticles on posterolateral border. Denticulation mainly on basal portion of gill rakers. Olfactory rosette circular in shape and with 12 (2) or 13 (1) lamellae in left and right sides of central median raphe.

Color in alcohol. Overall body color pale yellow to light brown. Dorsal surface of head from snout to anterior limit of frontal pale yellow, black chromatophores noticeably more concentrated in region of parietal and supraoccipital bones. Region of third to fourth infraorbitals and opercular apparatus silver. Dorsum from posterior limit of supraoccipital to caudal peduncle with dark gray chromatophores more concentrated on scales border. Ventral region between pectoral and pelvic fins light yellow. Humeral region with slightly darkened triangular area due to muscular hiatus of pseudotympanum. Body with silver lateral band between pseudotympanum and caudal peduncle. Caudal peduncle with brown rhomboid spot, not reaching dorsal and ventral borders of caudal peduncle, covering basal portion of central rays of caudal fin.

Dorsal fin translucent, with few chromatophores scattered in anterior rays. Black chromatophores along 
first unbranched pectoral-fin ray. Pelvic fin hyaline. Anal fin hyaline with light gray chromatophores in basal portion of anterior rays. Adipose fin hyaline with light gray chromatophores basally. Caudal-fin ray hyaline with basal portion covered by caudal peduncle spot.

Coloration of paratype CAS 59791 badly preserved, characterized by long silver lateral band extending from region immediately posterior to pseudotympanum to near caudal-fin base.

Color in life. Caudal spot black, not reaching upper and lower margin of caudal peduncle and extending to base of caudal fin, followed by silvery pigments in each lobe. Medial part of dorsal and anal fins gold silvery. Lateral band dark green with golden line on upper margin, extending from pseudotympanum to caudal spot. Body silvery, with scattered dark chromatophores on scales and fins.
Sexual dimorphism. Sexually mature males with small hooks on anal and pelvic fins. Anal-fin rays (Fig. 12c, d) with one pair of retrorse bony hooks per ray segment symmetrically distributed, with robust base and curved or straight tips, present on last unbranched ray and anterior 6 to 8 branched rays, decreasing in number posteriorly. Bony hooks present on median portion of posterior branch, absent on anterior branch. Tip of bony hooks not reaching proximal border of segment of lepidotrichia where inserted. Pelvic-fin rays (Fig. 12e,f) with small hooks on all branched rays; hooks retrorse with robust base and curved tips inserted on median and distal partions of fin rays, some very small hooks on distal border of proximal portion. One bony hook, per segment on posterolateral border of anterior and posterior lepidotrichia in median portion and on posterolateral border of posterior lepidotrichia in distal portion. Tip of bony hooks not reaching proximal border of segment of lepidotrichia where inserted.

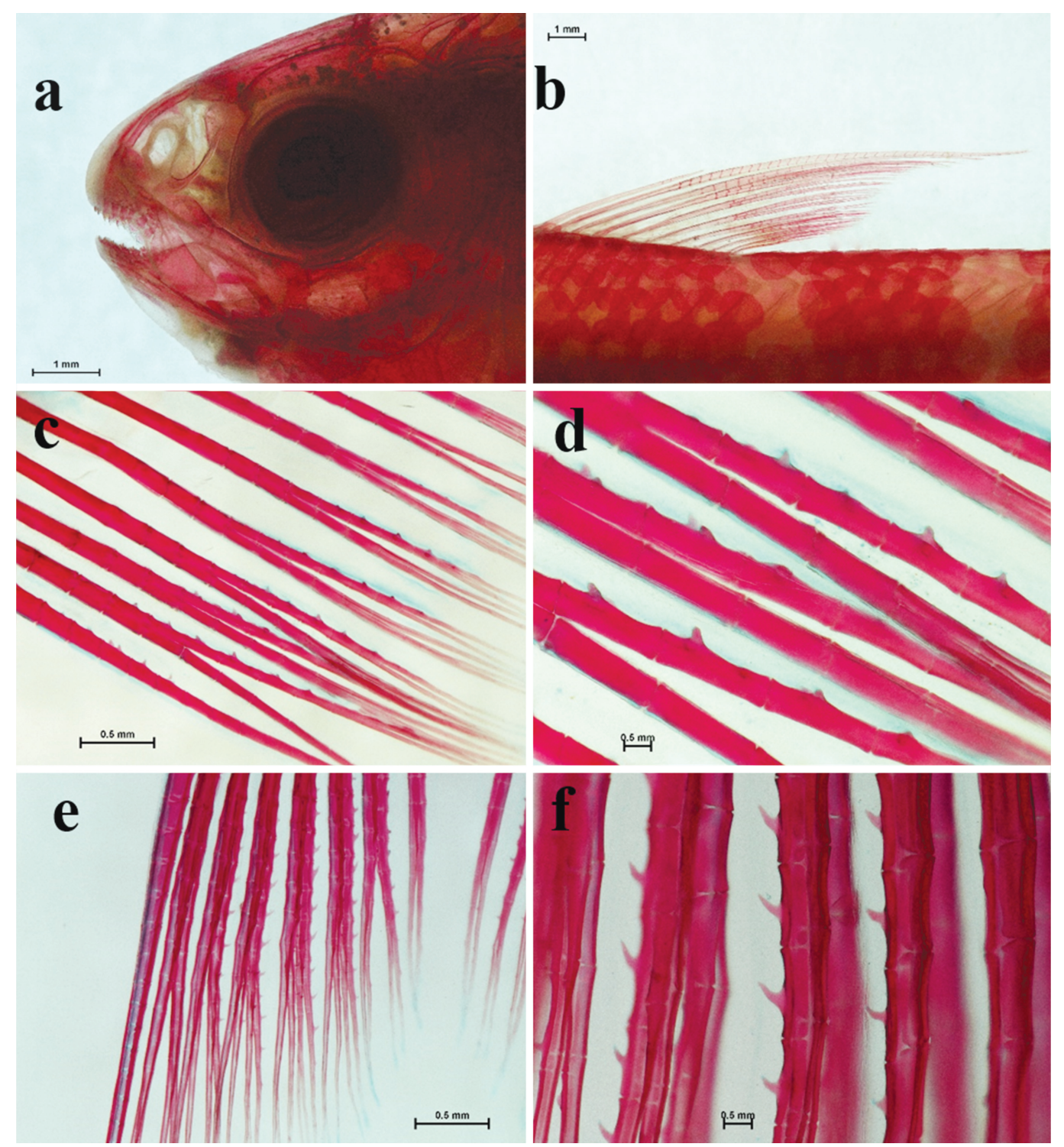

Fig. 12. Odontostilbe microcephala. Male (MCP 38311): (a) Subterminal mouth (b) Second unbranched of dorsal fin elongate. Male (USNM 321173): (c) and (d) hooks in anal-fin rays; (e) and (f) hooks in pelvic-fin rays. 
Geographic distribution. Odontostilbe microcephala is known from río Pilcomayo, río Paraguay basin, in Bolivia and Argentina and río Masicuri, headwaters of rio Mamoré, Amazon basin, in Bolivia (Fig. 6). Carvalho, Albert, (2011) discuss the distribution of Odontostilbe microcephala between the Paraguay and Mamoré basins that is located mainly in the Chaco Plain and traversed by several major rivers (i.e., Parapetí, Grande, and Pilcomayo rivers), where typical taxa from the La Plata and upper Madeira basins occurs, due possibly to an exchange of water during the rainy season. O. microcephala is also distributed in the río Bermejo, río Juramento and río Sali-Dulce basins, in Northwestern Argentina (Mirande, Aguilera, 2009) and arheic basin of río Horcones a tributary of the río Salado. The first two basins are parallel to the Pilcomayo and drains into the Paraguay and Paraná rivers. The Sali-Dulce basin is endorheic.

Ecological notes. Examination of gut contents of two specimens of Odontostilbe microcephala (USNM 305484) revealed the presence of insect larvae, composed of a high number of nymphs of Ephemeroptera and pupae of Diptera, followed by larvae of Trichoptera and allochthonous adults of Hymenoptera (Vespidae).

Rondineli et al. (2011) described the species as insectivorous based on specimens collected from the rio Corumbataí (São Paulo, Brazil). The material examined by Rondineli and co-authors is possibly Odontostilbe avanhandava or $O$. weitzmani since $O$. microcephala does not occur in the upper rio Paraná. These authors, however, do not provide any descriptive information or photo of the fish he examined, not allowing confirmation of the identifications.

Conservation status. Odontostilbe microcephala is categorized as Least Concern (LC), according to the IUCN criteria for evaluation on threatening status, version 3.1 (Reis, Lima, 2009), due to its wide distribution and the lack of any known major threats across its range. For this categorization, Reis, Lima (2009) not considered the individuals of the upper part of the Paraná basin (currently $O$. weitzmani and O. avanhandava), due to this their current categorization of threat does not vary.

Remarks. Odontostilbe microcephala was briefly described by Eigenmann (in Eigenmann, Ogle, 1907) based on two specimens from the río Pilcomayo in Bolivia. Eigenmann (1915) redescribed the species with more detail based on the type specimens plus some specimens collected in the rio Tietê, São Paulo, Brazil (CAS 60508, FMNH 57871, FMNH 57872, FMNH 131317), and extended its distribution to the upper rio Paraná basin. Specimens examined by Eigenmann (1915), however, were analyzed herein and belong to the two new above described species, and no specimens of $O$. microcephala were found among the material available from the upper rio Paraná basin. Due to the redescription of Eigenmann (1915), the name of O. microcephala has been cited for the upper rio Paraná basin in different studies (e.g. Oyakawa, Menezes, 2011). This species is now restricted to the Andean slope of the río Paraguay and edorheic río Salí basin (Argentina and Bolivia).

Material examined. Holotype CAS 59790, 1, 46.0 mm SL, río Pilcomayo, Bolivia, tributary of río Paraguay, $21^{\circ} 11^{\prime} 32^{\prime \prime} \mathrm{S}$ 634'32"W, 1900-1901. Paratype CAS 59791, 1, 45.0 mm SL, río Pilcomayo, Bolivia, tributary of río Paraguay, 20 $43^{\prime} 30^{\prime \prime} \mathrm{S}$

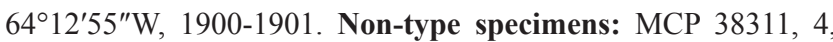
38.9-43.6 mm SL, endorheic of río Uruena, drainage of Bajo Paraná, Rosario de la Frontera, Salta, Argentina, $25^{\circ} 00^{\prime} 00^{\prime \prime} \mathrm{S} 64^{\circ} 30^{\prime} 00^{\prime \prime} \mathrm{W}, 2$ Mar 2001, G. Monasterio de Gonzo \& M. Mosqueira. MCP 38310 , 4, 39.8-55.3 mm SL, arheic basin of río Horcones, Salta, Rosario de la Frontera, Argentina, $25^{\circ} 00^{\prime} 00^{\prime \prime} \mathrm{S}, 64^{\circ} 30^{\prime} 00^{\prime \prime} \mathrm{W}, 03$ Mar 2001, G. Monasterio de Gonzo \& M. Mosqueira. USNM 176033, 1, $48.9 \mathrm{~mm}$ SL, río Dulce, endorheic, afluent Mar Chiquita Lake Argentina, 29³8'47"S 62 ${ }^{\circ} 52^{\prime} 19^{\prime \prime} \mathrm{W}, 1$ Aug 1933, T. Marini. UMSS 473, 6, 37.4-43.0 mm SL, río Masicurí, farm Piraymiri, río Grande, río Mamoré, río Madera, río Amazonas, Bolivia, 1850’36"S $63^{\circ} 45^{\prime} 32^{\prime \prime} \mathrm{W}, 22$ nov 2005, L. Cordova, M. Maldonado, M. Arraya, USNM 306349, 2, 41.7-47.4 mm SL, rio Bermejo, 4-5 km S, Pueblo Salado, 30 air KM NW Bermejo, border of Department of Tarija, río Paraguay, Argentina-Bolivia, $22^{\circ} 27^{\prime} 00^{\prime \prime} \mathrm{S} 64^{\circ} 32^{\prime} 00^{\prime \prime} \mathrm{W}, 5$ Oct 1988, W. Starnes, L. Starnes, J. Sarmiento \& R. Vasquez. USNM 305484, 109, 33.54-51.97 mm SL, río Pilcomayo, Department of Tarija, at Villamontes rr Bridge, río Paraguay, Bolivia, $21^{\circ} 16^{\prime} 48^{\prime \prime} \mathrm{S}$ $63^{\circ} 28^{\prime} 12^{\prime \prime}$ W, 1 Oct 1988 , W. Starnes, L. Starnes, J. Sarmiento \& R. Vasquez. USNM 321173, 49, 29.7-44.0 mm SL (2 c\&s, 30.6$44.0 \mathrm{~mm} \mathrm{SL}$ ), río Camatindi, $8 \mathrm{Km}$ N Border Department of Tarija, $40 \mathrm{Km}$ N Villamontes, Department Chuquisaca, riío Paraguay, Bolivia, 2059'34"S 6323'51"W, 2 Oct 1988 Cols W. Starnes, L. Starnes, J. Sarmiento \& R. Vasquez. USNM 319279, 200, $21.96-$ $38.04 \mathrm{~mm}$ SL, rio Parapeti, at Rr bridge at San Antonio, 40 Air km E Camiri, Department Santa Cruz, Amazon and Paraguay, Bolivia, $20^{\circ} 01^{\prime} 12^{\prime \prime S} 63^{\circ} 12^{\prime} 00^{\prime \prime} \mathrm{W}, 30$ Sep 1988, W. Starnes, L. Starnes, J. Sarmiento \& R. Vasquez. MHNG 2653.042, 2, 38.8-40.9 mm SL, Pazo Hondo, río Pilcomayo, Paraguay, 12 Aug 1994, C.Dlouhy.

Comparative material examined. Odontostilbe fugitiva: Perú: ANSP 178908, 2 c\&s, 29.5-32.5 mm SL. Brazil: INPA 18506, 3 c\&s, 24.5-32.4 mm SL. INPA 18512, 1 c\&s, $34.9 \mathrm{~mm}$ SL. Ecuador: MZUSP 77844, 2 c\&s, 36.9-40.0 mm SL. Odontostilbe pulchra: Trinidad and Tobago: INHS 40101, 3 c\&s, 32.5-34.4 mm SL. INHS 40081, 1 c\&s, 30.5 mm SL. Odontostilbe nareuda: Brazil: MZUSP 87759, 1 c\&s, $27.5 \mathrm{~mm}$ SL. Bolivia: FMNH 106433, 1 c\&s, $31.6 \mathrm{~mm}$ SL. Odontostilbe dierythrura: Bolivia: MCP 38624, 7 (2 c\&s, 33.5-38.4 mm SL), 32.7-34.5 mm SL. Odontostilbe euspilurus: Perú: ANSP 143702, 2 c\&s, 29.5-33.1 mm SL. Ecuador: MCP 38420, 13, 35.2-41.2 mm SL. Odontostilbe paraguayensis: Brazil: MCP 35618, 54, 28.5-33.9 mm SL. Paraguay: MCP 12031, 3, 30.92-33.90 mm SL. Odontostilbe pequira: Brazil: UFRGS 7022, 2 c\& 36.7-38.7 mm SL, UFRGS 8641, 14, 32.0-46.6 mm SL. UFRGS 5589, 5, 31.5-34.0 mm SL. UFRGS 13365, 22, 37.6-33.9 mm SL. UFRGS 13006, 99, 26.6$34.7 \mathrm{~mm}$ SL. Brazil. MZUSP 21067, 1 c\&s, $31.0 \mathrm{~mm}$ SL. 
Morphometric comparisons. The results of the PCA of morphometric data (Fig. 13) are congruent with the morphological analysis in delimitating Odontostilbe avanhandava, O. microcephala, and O. weitzmani. Although overlapping, the boxplot graphic of lateral line scales count shows differences between $O$. microcephala vs. O. weitzmani and $O$. avanhandava vs. O. weitzmani, and that $O$. avanhandava and $O$. microcephala present a smaller overlap. Furthermore, although overlapping branched anal-fin rays count are also different between $O$. avanhandava vs. O. weitzmani and slight different between O. avanhandava and O. microcephala (Fig. 14).

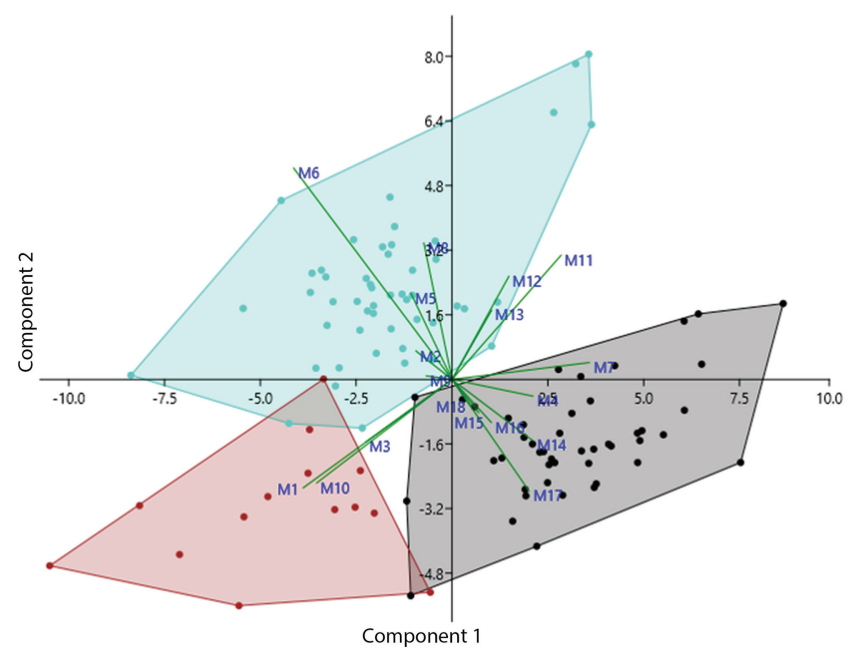

Fig. 13. Principal Components Analysis (PCA) between the species Odontostilbe avanhandava (red) O. microcephala (light blue) and O. weitzmani (black).
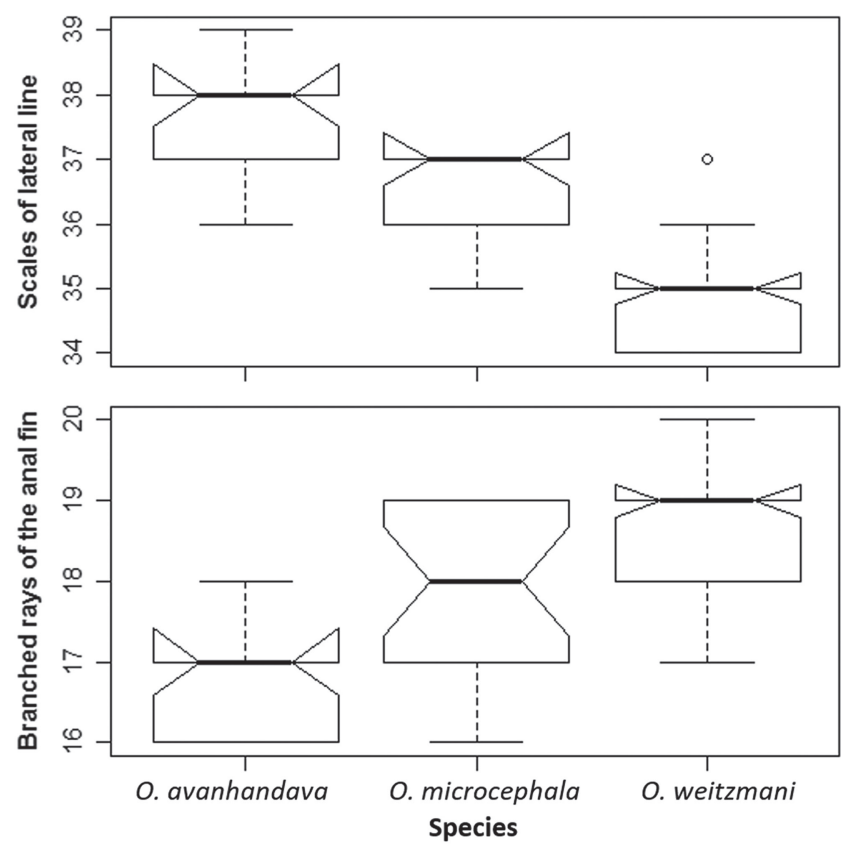

Fig. 14. Box-plot graphics of Odontostilbe avanhandava, $O$. microcephala and $O$. weitzmani: lateral line series of scales (top); and branched rays of the anal fin (bottom).
The variable that best discriminate $O$. microcephala and O. weitzmani (Fig. 15), is M17 (horizontal orbit diameter), not overlaping between both species and presenting a high discrimination capacity (Fig. 15a). Other variable with high discrimination capacity is M6 (orbit-dorsal fin origin). The scatterplot of polar coordinates obtained for both species using M17 and M6 (Fig. 15b) shows the differences between $O$. microcephala and $O$. weitzmani. The bivariate randomization test also separates individuals of both species. The individual of $O$. microcephala (Fig. 15c, red point) with the higher probability of belonging to $O$. weitzmani, with $\mathrm{p}=0.019$ for $\mathrm{X}$-axis, is not included among the specimens belonging to $O$. weitzmani, rejecting the null hypothesis. Consequently, the X polar coordinates of all individuals of $O$. microcephala are significantly different from those of $O$. weitzmani and, therefore, none of the individuals identified as $O$. microcephala could be designated as belonging to $O$. weitzmani. The same is found for the individual of $O$. weitzmani (Fig. 15d, red point) with higher probability of belonging to $O$. microcephala $(\mathrm{p}=0.025$ for $\mathrm{X}$-axis), rejecting the null hypothesis, consequently the $\mathrm{X}$ polar coordinates of all individuals of $O$. weitzmani are significantly different from those of $O$. microcephala. Repeating this same analysis, variables that best discriminate $O$. avanhandava and $\mathrm{O}$. weitzmani are M1 (snout to anal-fin origin) and M7 (anal-fin base length), from $O$. avanhandava and O. microcephala are M1 and M17 (horizontal orbit diameter).

\section{Discussion}

Over the course of the taxonomic history, some species of Odontostilbe have been wrongly identified, mainly due to problems in the original descriptions made at the beginning of the XX Century. It is the case of Odontostilbe microcephala described originally from Bolivia (Eigenmann in Eigenmann, Ogle, 1907), and redescribed by Eigenmann (1915) with inclusion of material from the upper rio Paraná basin. The most part of this material was herein reviewed, concluding that specimens used in the redescription belong to Odontostilbe avanhandava and $O$. weitzmani, endemic to the upper rio Paraná basin.

Based on our analysis, Odontostilbe avanhandava, $O$. microcephala, and $O$. weitzmani can be clearly diagnosed based in the mouth position, tooth cusp number, number of lamellae in the olfactory rosette, number of gill rakers in the upper and lower branch, horizontal orbit diameter, head size, snout to anal-fin origin distance, number of branched rays of the anal-fin, perforated scales of lateral line and form of hooks in the pelvic fin.

Hooks on the fins are variable in the Cheirodontinae and their number, size, shape, arrangement on fin-rays or presence in a specific fin have been described as diagnostic for some genera of the subfamily, like Acinocheirodon (Malabarba, Weitzman, 1999), Kolpotocheirodon (Malabarba et al., 2004), Macropsobrycon (Jerep, Malabarba, 2011), Ctenocheirodon (Malabarba, Jerep, 2012), and Serrapinnus (Malabarba, 
Jerep, 2014). The presence and morphology of these bony hooks represent an important data source for comparative phylogenetic, reproductive and behavioral studies (Bertaco, Malabarba, 2005; Vieira et al., 2016). Even though they are usually less developed and less informative in the species of Odontostilbe, their number and size were useful to diagnose $O$. avanhandava, O. microcephala, and $O$. weitzmani.

Differences in the mouth position were found among species of Odontostilbe previously described by Bührnheim, Malabarba $(2006,2007)$, with terminal mouth observed in O. ecuadorensis, O. fugitiva, O. nareuda, O. pao, O. paraguayensis, O. parecis, O. pequira, O. pulchra, O. splendida, and $O$. weitzmani, and subterminal mouth in $O$. avanhandava, $O$. dierythrura, O. euspilurus and $O$. microcephala. This variation in mouth position may reflect differences in feeding habits, such as mode of foraging, orientation, or diet composition. Species that feed in midwater often have terminal mouth, while benthic feeders exhibit subterminal mouth (Keast, Webb, 1966; Langerhans et al., 2003).
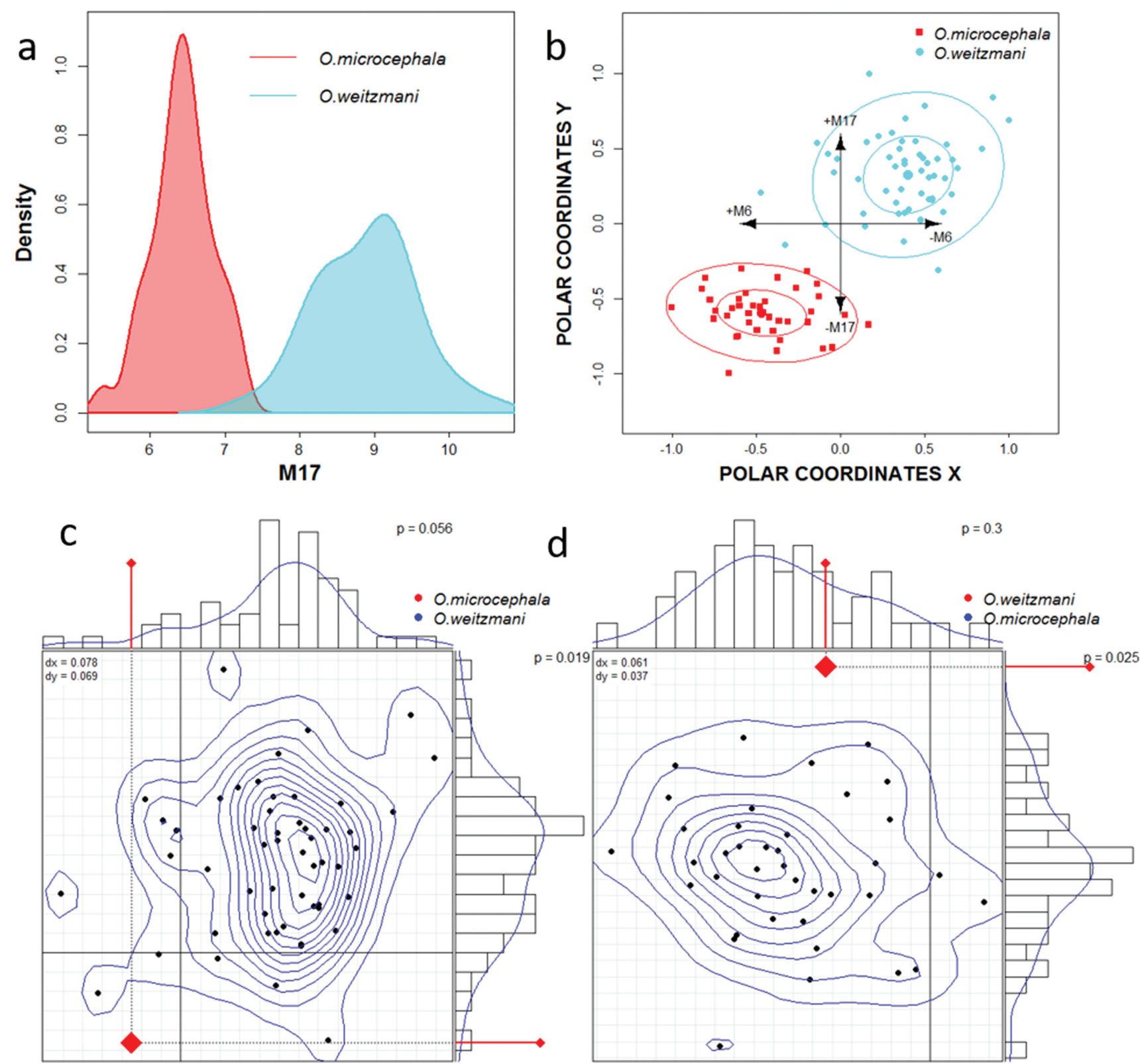

Fig. 15. Morphometric comparison of Odontostilbe microcephala and O. weitzmani. (a) Density plot with the overlap of the variable M17 (horizontal orbit diameter), that best discriminates the two species. (b) Scatterplot of the polar coordinates obtained for both species using variables M17 and M6 (orbit to dorsal-fin origin); the arrows show the vector of variables. (c) Bivariate randomization test, showing the individual (red point) with a higher probability of belonging to O. weitzmani among all included individuals identified as $O$. microcephala. (d) Bivariate randomization test, showing the individual (red point) with a higher probability of belonging to $O$. microcephala among all individuals identified as $O$. weitzmani. 
The shape and number of gill rakers in the lower and upper branch of the first branchial arch have been described recently for some species of Odontostilbe, being a character that varies slightly between species (Bührnheim, Malabarba, 2006, 2007). Odontostilbe microcephala, however, shows the highest number of gill rakers (upper 10, lower 14-15), comparatively to other species : O. avanhandava (upper 6, lower 12), $O$. ecuadorensis (upper 5-6, lower 10-11), O. fugitiva (upper 6-8, lower 11-14), O. nareuda (upper 5-6, lower 10-12), O. pao (upper 6, lower 11), O. weitzmani (upper 5, lower 10) , O. parecis (upper 5-6, lower 9-10), O. pulchra (upper 6-7, lower 11-12), and O. splendida (upper 5-6, lower10-12). The number of gill rakers, may play an important role in food-particle retention, particularly with respect to zooplankton feeding (MacNeil, Brandt, 1990; Amundsen et al., 2004), and may reflect differences in the feeding habits of $O$. microcephala.

Description of denticles on the gill rakers was provided for the first time for species of the Cheirodontinae by Bührnheim, Malabarba (2006); this character was considered in the phylogeny of Characidae by Mirande (2010: character 201). Denticles on gill rakers of the first branchial arch are found among all groups of Characiformes, especially in Characidae, being its absence observed in some Characidae as for example the Gymnocharacinae, Axelrodia lindeae Géry 1973, and Pseudochalceus kyburzi Schultz 1966 (Mirande, 2010). When present, the denticles may be restricted to one margin or be distributed along of the entire surface of gill rakers as in Astyanax puka Mirande et al. (2007). The number of denticles on anterolateral border of the gill rakers presents large intraspecific variation: O. ecuadorensis (upper 1-6, lower 1-6), Odontostilbe fugitiva (upper 1-5, lower 1-4), O. nareuda (upper 1-3, lower 0-3), O. pao (upper 1-2, lower 0-2), O. paraguayensis (upper 0-2, lower 4-6), $O$. parecis (upper 1-3, lower 0-5), O. pulchra (upper 1-4, lower 1-6), and O. splendida (upper 0-3, lower 1-4). Odontostilbe microcephala (upper 3-4, lower 4) presents the denticulation mainly on basal portion of gill rakers, differing from $O$. weitzmani (upper 4-5, lower 3-6) that presents the denticles also on the lateral surfaces of gill rakers.

Mesopterygoid teeth were reported, among the Characiformes, in Hoplerythrinus unitaeniatus (Spix, Agassiz) (Weitzman, 1964), Boulengerella Eigenmann (Vari, 1995), Crenuchus Günther and Ammocryptocharax vintonae (Eigenmann) (Buckup, 1993), Acestrorhynchus Eigenmann, Kennedy and Cynodontinae (Lucena, Menezes, 1998; Toledo-Piza, 2000), and Roeboides dispar (Lucena, 2001). Mesopterygoid teeth can present interspecific and/or ontogenetic variation, being present in some individuals and absent in others within the same species (Toledo-Piza, 2000). In Odontostilbe, this character is known only in $O$. avanhandava and $O$. weitzmani.
Generic assignment of the new species. Cope (1970) diagnosed Odontostilbe based on three characters that are currently shared with other species of Cheirodontinae: the teeth spatulate and crenate in a single series on the premaxilla and dentary, the anal fin elongated and the lateral line continued to the caudal fin. Malabarba (1998) proposed two synapomorphies to diagnose Odontostilbe related to the length of the second branched ray of the dorsal fin and length of the first unbranched ray of the pelvic fin in males. More recently, Bührnheim, Malabarba (2006, 2007) used this criterion to describe five new species to this genus (O. ecuadorensis, O. nareuda, O. pao, O. parecis, and $O$. splendida), along with the redescription of $O$. pulchra and its type species Odontostilbe fugitiva. Odontostilbe weitzmani and $O$. microcephala present the two synapomorphies proposed by Malabarba (1998) for the genus.

The elongation of second branched ray of the dorsal fin and the unbranched ray of the pelvic fin in males is not an exclusive character of Odontostilbe. It has been recorded in Cheirodontops geayi (Bührnheim, Malabarba, 2006), but that species differs from Odontostilbe by the premaxillary teeth with only 3 cusps. It is also found in Serrapinnus tocantinensis Malabarba, Jerep (2014), but that species shares with other Serrapinnus the caudal peduncle conspicuously arched ventrally in mature males and several other synapomorphies of the Cheirodontini not shared with the species of Odontostilbe (Malabarba, Jerep, 2014).

Recently, Mariguela et al. (2013) proposed Odontostilbe as polyphyletic in a phylogenetic analysis based on molecular data. According to Mariguela et al. (2013), $O$. pequira and an undescribed species (Odontostilbe sp. 2) are grouped in their clade 8, including species of Serrapinnus, Acinocheirodon, and Aphyocheirodon: (Aphyocheirodon + Acinocheirodon) form the sister group of (Serrapinnus microdon $(O$. pequira $+(O$. sp. $2+S$. heterodon $))$ ). Five species were recovered as belonging to their clade 11 , including the type species of the genus: $(O$. splendida + $O$. pulchra) form the sister group of (Ctenocheirodon pristis (S. kriegi (O. fugitiva $+(O$. ecuadorensis $+O$. paraguayensis $)+((S$. piaba + Compsura heterura $)+S$. calliurus $(S$. calliurus $+S$. notomelas $))))$ ). Finally, the two species provisionally housed in Odontostilbe were recovered as related to Saccoderma and an undescribed Compsura in their clade 4: (Saccoderma melanostigma ("Odontostilbe" mitoptera + C. gorgonae) + ("O." dialeptura + Compsura sp.)). Based on these results, Mariguela et al. (2013) proposed a new classification of the tribes in Cheirodontinae, but ignoring numerous evidences, including those associated to the primary and secondary sexual characters, which contradict the monophyly of their clades 1 and 2, and support instead the monophyly of the Cheirodontini and Compsurini sensu Malabarba (1998). The clade 3 presents "Odontostilbe" dialeptura and "Odontostilbe" mitoptera as belonging to another clade, related to fishes of Central America, corroborating the results obtained by Malabarba (1998) in this sense. 
Bührnheim, Malabarba (2006) considered that these species need to be excluded from Odontostilbe but in the lack of a proper generic name they are provisionally kept in "Odontostilbe". Characters diagnosing Odontostilbe and its relationships must be reviewed in an integrative analysis, given the recent addition of new species to the genus and the conflicting hypotheses presented in morphological and molecular analyses.

\section{Acknowledgments}

The authors are grateful to Osvaldo Oyakawa, Michel Gianeti and Alessio Datovo (MZUSP), Carlos Lucena and Roberto Reis (PUCRS), Hernán Ortega (MUSM), Fernando M. Carvajal-Vallejos (UMSS), Dave Catania (CAS), Ana Cláudia Santos (IF Birigui, SP)), Caleb McMahan (FMNH) for museum and technical support and/or loan of specimens. Dave Catania (ANSP) and Caleb McMahan (FMNH) for photographs and radiographs of type material. Marcos Mirande (Fundación Miguel Lillo - CONICET) by sending information, Vanessa Meza (PUCRS) helped to produce figure 6. Dario Faustino (UFRGS) helped to produce of the photos of the type. We also thank Carlos Lucena (MCP) and Vinicius Bertaco (FZB/RS) for review of the manuscript previous to submission. We also thank Marco Mirande, Fernando Carvalho (UFMS) and Fernando Jerep (UEL) for review of the manuscript. JC was supported by a master's fellowship from CNPq from the Programa de Pós-Graduação em Biologia Animal-UFRGS.

\section{References}

Amundsen PA, Bøhn T, Våga G. Gill raker morphology and feeding ecology of two sympatric morphs of European whitefish (Coregonus lavaretus). Ann Zool Fenn [serial on the internet]. 2004; 41(1):291-300.

Bertaco VA, Malabarba LR. A new species of Hyphessobrycon (Teleostei: Characidae) from the upper rio Tocantins drainage, with bony hooks on fins. Neotrop Ichthyol [serial on the internet]. 2005; 3(1):83-88. Available from: https://dx.doi. org/10.1590/S1679-62252005000100004

Bivand RS, Pebesma EJ, Gómez-Rubio V. Applied spatial data analysis with R. 2nd ed. New York (NY): Springer; 2013.

Bowman AW, Azzalini A. smoothing methods for nonparametric regression and density estimation [Computer software manual - internet], R package 'sm' version 2.2-5.4; 2013. Available from: https://cran.r-project.org/web/packages/sm/index.html

Buckup PA. Phylogenetic interrelationships and reductive evolution in Neotropical Characidiin fishes (Characiformes, Ostariophysi). Cladistics [serial on the internet]. 1993; 9(3):305-41. Available from: http://dx.doi. org/10.1111/j.1096-0031.1993.tb00227.x

Bührnheim CM, Malabarba LR. Redescription of the type species of Odontostilbe Cope, 1870 (Teleostei: Characidae: Cheirodontinae), and description of three new species from the Amazon basin. Neotrop Ichthyol [serial on the internet]. 2006; 4(2):167-96. Available from: http://dx.doi.org/10.1590/ s1679-62252006000200004
Bührnheim CM, Malabarba LR. Redescription of Odontostilbe pulchra (Gill, 1858) (Teleostei: Characidae: Cheirodontinae), and description of two new species from the río Orinoco basin. Neotrop Ichthyol [serial on the internet]. 2007; 5(1):1-20. Available from: http://dx.doi.org/10.1590/s167962252007000100001

Bührnheim CM, Carvalho TP, Malabarba LR, Weitzman SH. A new genus and species of characid fish from the Amazon basin - the recognition of a relictual lineage of characid fishes (Ostariophysi: Cheirodontinae: Cheirodontini). Neotrop Ichthyol [serial on the internet]. 2008; 6(4):663-78. Available from: http://dx.doi.org/10.1590/s1679-62252008000400016

Calenge C. The package "adehabitat" for the R software: a tool for the analysis of space and habitat use by animals. Ecol Modell [serial on the internet]. 2006; 197(3-4):516-19. Available from: http://dx.doi.org/10.1016/j.ecolmodel.2006.03.017

Canty A, Ripley B. boot: Bootstrap R (S-Plus) Functions [computer software manual - internet]. R package version 1.3-18; 2016. Available from: https://cran.r-project.org/web/packages/boot/ index.html

Carvalho TP, Albert JS. The Amazon-Paraguay Divide. In: Albert JS, Reis RE, editors. Historical Biogeography of Neotropical Freshwater Fishes. Los Angeles: University of California Press; 2011.

Casciotta JR, Miquelarena AM, Protogino L. A new species Odontostilbe (Teleostei, Characidae) from the Uruguay Basin, with comments on the diagnostic characters of the genus. Sci Pap Univ Kansas Nat Hist Mus. 1992; 149:1-16.

Chessel D, Dufour AB, Thioulouse J. The ade4 package-I: Onetable methods. R J. 2004; 4(1):5-10.

Cope ED. Contribution to the ichthyology of the Marañon. Proc Am Philos Soc. 1970; 11(81):559-70.

Davison AC, Hinkley DV. Bootstrap Methods and Their Applications (Cambridge series in statistical and probabilistic mathematics). Cambridge: Cambridge University Press; 1997.

Dray S, Dufour AB, Chessel D. The ade4 package - II: Two-table and K-table methods. R J. 2007; 7(2):47-52.

Dray S, Dufour AB, Thioulouse J. ade4: Analysis of ecological data: Exploratory and euclidean methods in environmental sciences [computer software manual - internet]. R package version 1.7-2; 2015. Available from: https://rdrr.io/cran/ade4/

Eigenmann $\mathrm{CH}$. Catalogue of the fresh-water fishes of tropical and south temperate America. In: Scott WB, editor. Reports of the Princeton University expeditions to Patagonia 1896-1899. Princeton: Princeton University; 1910 (Zöology, vol. 3).

Eigenmann $\mathrm{CH}$. The Cheirodontinae, a subfamily of minute characid fishes of South America. Ann Carnegie Mus [serial on the internet]. 1915; 7(1):1-100.

Eigenmann $\mathrm{CH}$, Ogle F. An annotated list of the characin fishes in the United States National Museum and the Museum Indiana University with description of new species. Proc US Natl Mus. 1907; 33:1-36.

Ekstrom C, Skovgaard M, Torben. kulife: Datasets and functions from the (now non-existing) Faculty of Life Sciences, University of Copenhagen [computer software manual internet], version 0.1-14; 2013. Available from: https://rdrr.io/ cran/kulife/

Fink WL, Weitzman SH. The so-called cheirodontin fishes of Central America with descriptions of two new species (Pisces: Characidae). Washington (DC): Smithsonian Institute Press; 1974. (Smithsonian Contributions to Zoology; No.172). 
Fowler HW. Zoological Results of the Second Bolivian Expedition for the Academy of Natural Sciences of Philadelphia, 1936-1937. Part I: The Fishes. Proc Acad Nat Sci Phila. 1940; 92:43-103.

Fox J, Weisberg S. An R Companion to Applied Regression. 2nd ed. Thousand Oaks (CA): Sage Publications Inc; 2011.

Géry J. Contribution à l'étude des poissons characoïdes de l'Équateur. Wiesbadenm Alemanha, DE: Franz Steiner; 1972. (Acta Humboldtiana. Series Geologica, Palaeontologica et Biologica; No. 2).

Géry J. Characoids of the world. Neptune city (NJ): T. F. H. Publications; 1977.

Guisande-González G. VARSEDIG: An Algorithm for Morphometric Characters Selection and Statistical Validation in Morphological Taxonomy [computer software manual - internet]. R package version 1.2; 2016.

Guisande C, Vari RP, Heine J, García-Roselló E, GonzálezDacosta J, Perez-Schofield BJG, González-Vilas L, PelayoVillamil P. VARSEDIG: an algorithm for morphometric characters selection and statistical validation in morphological taxonomy. Zootaxa [serial on the internet]. 2016; 4162(3):57180. http://dx.doi.org/10.11646/zootaxa.4162.3.10

Hammer Ø, Harper DAT, Ryan PD. PAST: Paleontological statistics software package for education and data analysis. Palaeontol Electronica [serial on the internet]. 2001; 4(1): 19. Available from: http://palaeo-electronica.org/2001_1/ past/issue1_01.htm

International Union for Conservation of Nature (IUCN). Standards and Petitions Subcommittee. Guidelines for using the IUCN red list categories and criteria. Version 13 [internet]. 2017 [updated 2017 Mar]. Available from: http:// cmsdocs.s3.amazonaws.com/RedListGuidelines.pdf

Jerep FC, Malabarba LR. Revision of the genus Macropsobrycon Eigenmann, 1915 (Characidae: Cheirodontinae: Compsurini). Neotrop Ichthyol [serial on the internet]. 2011; 9(2):299-312. Available from: https://dx.doi.org/10.1590/ S1679-62252011005000015

Jerep FC, Malabarba LR. Anew species of Serrapinnus Malabarba, 1998 (Teleostei: Characidae: Cheirodontinae) from Rio Grande do Norte State, northeastern Brazil. Neotrop Ichthyol [serial on the internet]. 2014; 12(2):301-08. Available from: http://dx.doi.org/10.1590/1982-0224-20130218

Jerep FC, Camelier P, Malabarba LR. Serrapinnus zanatae, a new species from rio Jequitinhonha basin, Minas Gerais state, Brazil (Teleostei: Characidae: Cheirodontinae). Ichthyol Explor Freshw. 2016; 26(4):289-98.

Keast A, Webb D. Mouth and body form relative to feeding ecology in the fish fauna of a small lake, Lake Opinicon, Ontario. Can J Fish Aquat Sci [serial on the internet]. 1966; 23(12):1845-74. Available from: http://dx.doi.org/10.1139/f66-175

Langerhans RB, Layman CA, Langerhans AK, Dewitt TJ. Habitat-associated morphological divergence in two Neotropical fish species. Biol J Linn Soc Lond [serial on the internet]. 2003; 80(4):689-98. Available from: http://dx.doi. org/10.1111/j.1095-8312.2003.00266.x

Lucena CAS, Menezes NA. A phylogenetic analysis of Roestes Günther and Gilbertolus Eigenmann, with a hypothesis of the relationships of the Cynodontidae and Acestrorhynchidae (Teleostei: Ostariophysi: Characiformes). In: Malabarba LR, Reis RE, Vari RP, Lucena ZMS, Lucena CAS, editors, Phylogeny and classification of Neotropical fishes. Porto Alegre: Edipucrs; 1998. p.261-277.
Lucena CAS. Uma nova espécie de Roeboides Günther da região superior da bacia Amazônica (Teleostei: Characiformes: Characidae). Biotemas [serial on the internet]. 2001; 14(2):6170. Available from: https://doi.org/10.5007/\%25x

Lund U, Agostinelli C. CircStats: Circular Statistics, from "Topics in circular Statistics" (2001) [Computer software manual - internet]. R package version 0.2-4; 2012. Available from: https://CRAN.R-project.org/package=CircStats

MacNeil DB, Brandt SB. Ontogenetic shifts in gill raker morphology and predicted prey capture efficiency of the alewife Alosa pseudoharengus. Copeia [serial on the internet]. 1990; (1):164-71. Available from: http://dx.doi. org/10.2307/1445832

Malabarba LR. Monophyly of the Cheirodontinae, characters and major clades (Ostariophysi: Characidae). In: Malabarba LR, Reis RE, Vari RP, Lucena ZMS, Lucena CAS, editors. Phylogeny and Classification of Neotropical Fishes. Porto Alegre: Edipucrs; 1998. p.193-233.

Malabarba LR. Subfamily Cheirodontinae (Characins, tetras). In: Reis RE, Kullander SO, Ferraris CJ Jr., organizers. Check list of the freshwater fishes of South and Central America. Porto Alegre: Edipucrs; 2003. p 215-21.

Malabarba LR, Bertaco VA. Description of a new species of Heterocheirodon Malabarba (Teleostei: Characidae: Cheirodontinae: Cheirodontini), with further comments on the diagnosis of the genus. Comun Mus Ciênc Tecnol PUCRS (Série Zoologia). 1999; 12:83-109.

Malabarba LR, Jerep FC. A new genus and species of cheirodontine fish from South America (Teleostei: Characidae). Copeia [serial on the internet]. 2012; 2012(2):243-50. Available from: http://dx.doi.org/10.1643/CI-11-143

Malabarba LR, Jerep FC. Review of the species of the genus Serrapinnus Malabarba, 1998 (Teleostei: Characidae: Cheirodontinae) from the rio Tocantins-Araguaia basin, with description of three new species. Zootaxa [serial on the internet]. 2014; 3847(1):57-79. Available from: http://dx.doi. org/10.11646/zootaxa.3847.1.3

Malabarba LR, Lima FCT, Weitzman SH. A new species of Kolpotocheirodon (Teleostei: Characidae: Cheirodontinae: Compsurini) from Bahia, Northeastern Brazil, with new diagnosis of the genus. Proc Biol Soc Wash [serial on the internet]. 2004; 117(3):317-29. Available from: http://www. biodiversitylibrary.org/item/23888

Malabarba LR, Weitzman SH. A new genus and new species of South American fishes (Teleostei: Characidae: Cheirodontinae) with a derived caudal fin, together with comments on internally inseminated cheirodontines. Proc Biol Soc Wash [serial on the internet]. 1999; 112(2):410-32. Available from: http://direct.biostor.org/reference/77858

Malabarba LR, Weitzman SH. A new genus and species of inseminating fish (Teleostei: Characidae: Cheirodontinae: Compsurini) from South America with uniquely derived caudal-fin dermal papillae. Proc Biol Soc Wash [serial on the internet]. 2000; 113(1):269-83. Available from: http://biostor. org/reference/81043.

Mariguela TC, Ortí G, Avelino GS, Abe KT, Oliveira C. Composition and interrelationships of a large Neotropical freshwater fish group, the subfamily Cheirodontinae (Characiformes: Characidae): a case study based on mitochondrial and nuclear DNA sequences. Mol Phylogenet Evol [serial on the internet]. 2013; 68(1):23-34. Available from: http://dx.doi.org/10.1016/j. ympev.2013.03.011 
Miquelarena AM, Mantinián JE, López HL. Peces de la Mesopotamia Argentina (Characiformes: Characidae: Cheirodontinae). Miscelánea - Insugeo. 2008; 17:51-90.

Mirande JM. Phylogeny of the family Characidae (Teleostei: Characiformes): from characters to taxonomy. Neotrop Ichthyol [serial on the internet]. 2010; 8(3):385-568. Available from: http://dx.doi.org/10.1590/S1679-62252010000300001

Mirande JM, Aguilera G. Los peces de la selva pedemontana del noroeste argentino. In: Brown AD, Blendinger PG, Lomáscolo T, García-Bes P, editors, Selva pedemontana de las Yungas, historia natural, ecología y manejo de un ecosistema en peligro. Tucumán: Ediciones del Subtrópico; 2009. p.169-211.

Mirande JM, Aguilera G, Azpelicueta MM. A new species of Astyanax (Characiformes: Characidae) from the endorheic Río Salí basin, Tucumán, northwestern Argentina. Zootaxa [serial on the internet]. 2007; 1646:31-39. Available from: https://doi. org/10.5281/zenodo. 179754

Oliveira CLC, Malabarba LR, Burns JR. Comparative morphology of gill glands in externally fertilizing and inseminating species of cheirodontine fishes, with implications on the phylogeny of the family Characidae (Actinopterygii: Characiformes). Neotrop Ichthyol [serial on the internet]. 2012; 10(2):34960. Available from: https://dx.doi.org/10.1590/S167962252012005000005

Oyakawa OT, Menezes NA. Checklist of fresh water fishes from São Paulo State, Brazil. Biota Neotrop [serial on the internet]. 2011; 11(1):19-32. Available from: https://dx.doi.org/10.1590/ S1676-06032011000500002

Pebesma EJ, Bivand RS. Classes and methods for spatial data in R. R J [serial on the internet]. 2005; 5(2):9-13. Available from: http://cran.r-project.org/doc/Rnews/

Quantum GIS Development Team. Quantum GIS Geographic Information System [Data Analysis Software System], version 2.8. 2016. Available from: http://qgis.org

$\mathrm{R}$ Development Core Team. R: a language and environment for statistical computing [Computer software manual - internet]. Vienna: R Foundation for statistical computing; 2016. Available from: https://www.r-project.org/

Reis R, Lima FCT. Odontostilbe microcephala. The IUCN red list of threatened species. 2009 [cited 2018 Feb 18]. Available from: http://dx.doi.org/10.2305/IUCN.UK.2009-2.RLTS. T167751A6376836.en

Ringuelet RA, Arámburu RH, Arámburu AA. Los peces argentinos de agua dulce. La Plata: Comisión de Investigaciones Científicas de la Provincia de Buenos Aires; 1967.

Rondineli G, Gomiero LM, Carmassi AL, Braga FMS. Diet of fishes in Passa Cinco stream, Corumbataí River sub-basin, São Paulo state, Brazil. Braz J Biol [serial on the internet]. 2011; 71(1):157-67. Available from: http://dx.doi.org/10.1590/ S1519-69842011000100023

Santos AC, Gonçalves CC, Carvalho FR. Ichthyofauna of the "Cachoeira de São Roberto" and fishes of lower Preto River, upper Paraná River basin, Brazil. Biota Neotrop [serial on the internet]. 2017; 17(1):e20160196. Available from: http:// www.scielo.br/scielo.php?script $=$ sci_arttext\&pid $=$ S167606032017000100301\&lng=en

Taylor WR, Van Dyke GC. Revised procedures for staining and clearing small fishes and other vertebrates for bone and cartilage study. Cybium [serial on the internet]. 1985; 9(2):10719. Available from: http://sfi-cybium.fr/en/node/2423
Toledo-Piza M. The Neotropical fish subfamily Cynodontinae (Teleostei: Ostariophysi: Characiformes): a phylogenetic study and a revision of Cynodon and Rhaphiodon. Am Mus Novit [serial on the internet]. 2000;3286:1-88. Available from: http://dx.doi.org/10.1206/0003-0082(2000)286<0001:TNFS $\mathrm{CT}>2.0 . \mathrm{CO} ; 2$

Turner R. Delaunay Triangulation and Dirichlet (Voronoi) Tessellation [Computer software manual - internet], package 'deldir'. R package version $0.1-12$; 2016. Available from: https://CRAN.R-project.org/package=deldir

Uj A. Les Cheirodontinae (Characidae, Ostariophysi) du Paraguai. Rev Suisse Zool [serial on the internet]. 1987; (94):129-75. Available from: http://dx.doi.org/10.5962/bhl.part.79716

Vari RP. The Neotropical fish family Ctenoluciidae (Teleostei: Ostariophysi: Characiformes): supra and infrafamilial phylogenetic relationships, with a revisionary study. Smithson Contrib Zool [serial on the internet]. 1995; 564:1-97. Available from: http://dx.doi.org/10.5479/si.00810282.564

Vari RP, Melo BF, Oliveira C. Protocheirodon, a new genus of Characidae (Teleostei: Characiformes) with the redescription of the poorly known Protocheirodon pi. Neotrop Ichthyol [serial on the internet]. 2016; 14(2):e150154. Available from: https://dx.doi.org/10.1590/1982-0224-20150154

Venables WN, Ripley BD. Modern Applied Statistics with S. New York: Springer; 2002. Available from: http://dx.doi. org/10.1007/978-0-387-21706-2

Vieira CS, Bartolette R, Brito MFG. Comparative morphology of bony hooks of the anal and pelvic fin in six neotropical characid fishes (Ostariophysi: Characiformes). Zool Anz [serial on the internet]. 2016; 260:57-62. Available from: http://dx.doi. org/10.1016/j.jcz.2016.01.003

Weitzman SH. The osteology of Brycon meeki, a generalized characid fish, with an osteological definition of the family. Stanford Ichthyol Bull; 1962; 8(1):3-77.

Weitzman SH. Osteology and relationship of South American characid fishes of subfamilies Lebiasininae and Erythrininae with special reference to subtribe Nannostomina. Proc US Nat Mus [serial on the internet]. 1964; 116:127-70. Available from: https://dx.doi.org/10.5479/si.00963801.116-3499.127

Weitzman SH, Malabarba LR. Systematics of Spintherobolus (Teleostei: Characidae: Cheirodontinae) from Eastern Brazil Ichthyol Explor Freshw. 1999; 10(1):1-43.

Zanata AM, Vari RP. The family Alestidae (Ostariophysi, Characiformes): a phylogenetic analysis of a trans-Atlantic clade. Zool J Linn Soc [serial on the internet]. 2005; 145(1):1-144. Available from: https://doi.org/10.1111/j.10963642.2005.00183.x

Zarske A. Serrapinnus sterbai spec. nov. - Beschreibung eines neuen Salmlers (Teleostei: Characiformes: Characidae: Cheirodontinae) aus Brasilien mit Bemerkungen zu S. gracilis (Géry, 1960) comb. nov. und S. littoris (Géry, 1960) comb.nov. Vertebr Zool [serial on the internet]. 2012; 62(1):3-17.

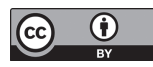

Submitted April 20, 2017 Accepted February 9, 2018 by Francisco Langeani 